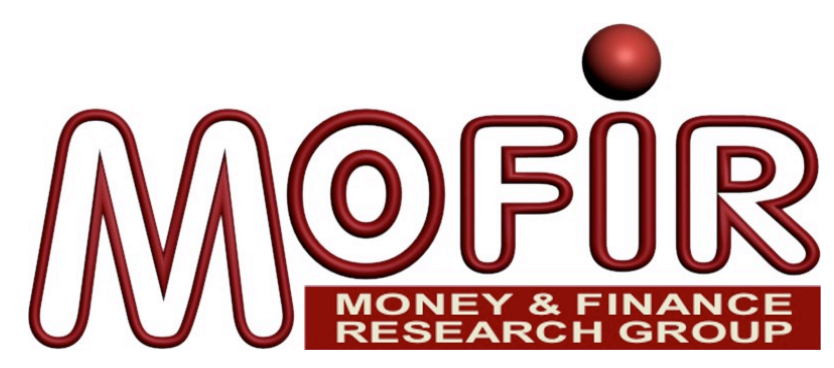

\title{
EXTERNAL IMBALANCES AND \\ FINANCIAL FRAGILITY IN THE EURO AREA
}

\author{
PIETRO ALESSANDRINI \\ Università Politecnica delle Marche \\ MoFiR \\ Michele FratianNi \\ Indiana University \\ Università Politecnica delle Marche \\ MoFiR \\ ANDREW Hughes HalletT \\ George Mason University \\ ANDREA F. PRESBITERO \\ Università Politecnica delle Marche \\ MoFiR \\ CeMaFiR
}

MoFiR working paper $n^{\circ} 66$

May 2012 
This draft: May 8, 2012

\title{
External imbalances and financial fragility in the euro area
}

\author{
Pietro Alessandrini*, Michele Fratianni**, \\ Andrew Hughes Hallett*** and Andrea F. Presbitero*
}

\begin{abstract}
$\underline{\text { Abstract }}$
This paper presents two views of the European sovereign debt crisis. The first is that the South in the euro zone has been fiscally irresponsible, and has failed to implement supply-side policies such as liberalizing labor markets and the market for services. The second view holds that the crisis reflects a deep divide between the external surpluses of the North and external deficits of the South. Basic stylized facts raise some doubt about the validity of the thesis that the debt crisis in the Eurozone is driven primarily by fiscal fragility in the South. A relatively simple model shows how poor fundamentals can create a debt problem independently of fiscal responsibility. The empirical analysis of the determinants of government bond yield spreads relative to Germany suggests that both views in fact provide useful insights into the roots of the current sovereign crisis. Fiscal fragility and external imbalances explain a significant share of the widening spreads since the onset of the global financial crisis. However, differences in labor productivity growth between North and South assume a much relevant role since the Greek crisis erupted in 2010.
\end{abstract}

JEL Classification: F32, F42, G12, H63.

Keywords: Sovereign yield spreads; external imbalances; adjustment burden; monetary union.

* Università Politecnica delle Marche and MoFiR, email: p.alessandrini@univpm.it and a.presbitero@univpm.it.

** Corresponding author, Indiana University, Università Politecnica delle Marche and MoFiR, email: fratiann@indiana.edu.

*** George Mason University, email: ahughesh@gmu.edu

We would like to thank, without implications, Gian Maria Milesi-Ferretti and Goetz Von Peter for having provided useful indication about data on financial flows. 


\section{Introduction}

This paper tries to answer the following three inter-related questions: Why is the speculative attack against sovereign debt taking place in the euro area (EA) in the aftermath of the financial crisis of 2008-2009? Why is that attack primarily focused on the South, and not on the North of the EA? Why is such a crisis not occurring outside the EA?

The current policy debate in the EA is predominantly centered on whether the ongoing fiscal austerity should be continued during depressed economic times. We can identify at least three different views in this debate: fiscal austerity in the South of the EA (simply the South) is necessary to resolve the debt crisis; fiscal austerity can make the debt crisis worse rather than better; and, an intermediate position, that the austerity measures need to be timed rather carefully.

The first view is the "German" view: fiscal austerity is essential to reduce the yield spreads of the government debt of the South relative to that of the "safe" German government debt, restore credibility in the South's ability to honor its debt, and lessen the risk of the South exiting the euro. The alternative of inflating away the problem by transforming the European Central Bank (ECB) into a lender of last resort to governments is not only unacceptable to the North, but violates the Treaty of the European Union; see Neumann (2012). The second view, the Keynesian, is that fiscal austerity is counter-productive, given the size of the fiscal multipliers, marginal tax rates and expected long-term growth rates. Fiscal austerity, rather than reduce budget deficits and debt-to-GDP ratios, may actually exacerbate the markets' doubts about government solvency; see DeLong and Summers (2012). The third view accepts the necessity of fiscal austerity but not under bad economic times, in other words the implementation of fiscal correction must take place when conditions warrant it; see Corsetti (2012) and IMF (2012).

Until recently, relatively little has been said in the policy debate about the euro-area crisis being just as much the result of external imbalances as of fiscal profligacy. In a sovereign country, inter-regional imbalances would pose no problem to the stability of the monetary union. But in the euro area they do. There are two reasons for this.

The first is that a monetary union needs the support of a significant centralized budget to absorb transitory, idiosyncratic shocks to individual member economies; in 
other words a fiscal union (Kenen 1969). In a monetary union, monetary policy can only stabilize aggregate shocks if they affect all members of the union equally. Real exchange-rate adjustments to idiosyncratic shocks, instead, must operate through changes in regional prices and wages. The fact that prices and wages are sluggish makes the adjustment process slow and leads to excessively long disequilibria in the output and labor markets. Therefore, it falls to fiscal policy to play the role of equilibrating regional differences in the fluctuations of output and employment (Fratianni and von Hagen 1992, ch. 8). Inadequate centralized fiscal instruments expose a monetary union to prolonged spells of regional economic disparities and, as a result, undermine the proper functioning of the union. It was in light of these considerations that the Delors Report (1989: 89) noted that: "[I]n all federations the different combinations of federal budgetary mechanisms have powerful "shockabsorber" effects, dampening the amplitude either of economic difficulties or of surges in prosperity of individual states. This is both the product of, and the source of the sense of national solidarity which all relevant economic and monetary unions share." Empirical work done in the 1980s and the 1990s confirmed the relevance of this view. ${ }^{1}$

The call for a sizable centralized fiscal budget to stabilize transitory regional shocks in an Economic and Monetary Union (EMU) is an old one, and goes back to the MacDougall Report (Commission of the EC 1977) which estimated that a budget of about five percent of the Community's GNP would be required for a viable EMU. The same report also indicated that central governments tend to redistribute resources among regions in a permanent way. For example, between 1971 and 1973, the poorer regions in the South of Italy received net public finance inflows averaging between 7.8 and 28 percent of their gross regional product. At the same time, their regional current-account deficits varied between 14.8 and 42.3 percent. In contrast, the relatively rich regions in the North had net public finance outflows between 4.4 and

\footnotetext{
${ }^{1}$ For example, Sachs and Sala-i-Martin (1989) contend that the U.S. federal fiscal system responds to regional shocks by offsetting about one-third of impact effects through counteraction tax and transfer payments. They, and Eichengreen (1990), conclude that an EMU without a sufficiently large fiscal apparatus would not work well.
} 
11.1 percent, compared with current account surpluses of 10.9 to 15.3 percent (Commission of the EC 1977: 33). ${ }^{2}$

The second reason why national imbalances may undermine the EA is that speculative attacks against individual members of the monetary union cannot be ruled out (Garber 1999). By contrast, speculative attacks against regions of a sovereign country can be ruled out. The argument goes as follows. The euro area has both a centralized monetary authority, the ECB, and national central banks (NCB). The fixity of the exchange rate among member countries is guaranteed by unlimited credit granted to each NCB through Target2, the online real-time payment system through which intra-euro area transactions are settled. These transactions arise from crossborder flows of goods and services, financial transactions or transfer of money (bank deposits) from one member country to another. If member countries had fixed exchange rates but different currencies, these cross-border transactions would have to be settled with international reserves. The common currency and the Target 2 mechanism have eliminated the need for such reserves. But an essential condition for the smooth operation of the euro area is that each NCB must have free access to credit through Target2. On the other hand, if there is "skepticism that a strong currency NCB will provide through Target2 unlimited credit in euros to the weak NCBs," sparked by "[a] large cross-border capital movement [that] may occur because of misplaced doubt about the continuation of a country in the monetary union, fear of a default on its bonds, or problems in its financial system that cause a bank run," then a precondition exists for a speculative attack (Garber 1999:211-12).

Before the liquidity crisis which erupted in the European interbank market in August of 2007, the Target 2 balances of individual NCBs were very small. After 2007, these balances have grown steadily. At the end of 2010, Germany had a credit balance of $€ 326$ billion and Greece, Ireland, Portugal and Spain an aggregate negative of $€ 340$ billion (Sinn and Wollmershäuser 2011, Figure 1). At the end of 2011, the

\footnotetext{
${ }^{2}$ The Italian redistribution of public resources from the North supplemented the inadequate capital inflows to South. In the years 1970-72 private net inflows, intermediated by banks and largely subsidized by government, accounted for 14.2 percent of the South GDP against a current-account deficit equal to 23.4 percent of the area's GDP. Such a situation has persisted to the present day. Longrun sustainability of the inter-regional current-account imbalances in the Italian monetary union was guaranteed not only by inter-regional flows of capital (both private and public) but also of labor: from 1951 to 1981, 25 per cent of the population has emigrated from the less developed Italian regions. On these issues see, among others, Tamagna and Qualeatti (1978), Alessandrini (1989), Galli (1990), and De Bonis et al. 2010.
} 
German credit balance had increased by more than $€ 100$ billion to a reported total of nearly $€ 1$ tn, while Italy had rapidly accumulated a deficit position of close to $€ 200$ billion (Bornhorst and Mody 2012, Figure 1). Sinn and Wollmershaeuser (2011) and European Economic Advisory Group (2012, ch. 2) claim that these imbalances represent a quasi-fiscal action by creditor NCBs (the North) in favor of debtor NCBs (the South) and are qualitatively not different from the assistance that the South already receives through the European Financial Stability Facility. ${ }^{3}$ In Germany, this issue is becoming politicized and gives additional credence to the point raised by Garber: the very fact that a discussion is taking place about ways to curtail or make these Target 2 debit balances more costly raises doubts about the availability of unlimited credit access in the Target 2 system and the possibility, remote as it may be, of a speculative currency attack on the euro - or, more likely, on the debt of the debtor economies. ${ }^{4}$

In sum, EA is structurally fragile; a fragility that was exposed by the financial crisis and government actions to rescue their banking systems. Investors' fears about this weak structure has manifested itself by attacking the euro through the government debt market. While these speculative attacks may reflect genuine concerns about the unsustainability of debt in the South, the deep divide between the external surplus of the North and the deficits in the South cannot be dismissed as a potential trigger mechanism for the debt crisis and its resistance to fiscal therapy. This stubborn resistance may well reflect an inadequate transfer mechanism that is normally present in sovereign states, disequilibrating real exchange rate movements, and low economic growth. These are old problems; but they have not been recognized sufficiently by the recent literature or policy practice. As a result, the present regime of fiscal austerity appears to be more a cure of a symptom than of the cause of the euro crisis.

The rest of the paper is organized as follows. In the second section we present some stylized facts of the sovereign debt crisis, facts that cast some doubt on the view that the sovereign debt crisis has been driven primarily by the lack of fiscal discipline in the South. The third lays out the two interpretations of the crisis and the related literature. Section four provides a general framework for analyzing an excess debt

\footnotetext{
${ }^{3}$ These authors propose to settle the balances in a way similar to how the US system requires of its District Federal Reserve Banks.

${ }^{4} \mathrm{~A}$ foundation of family-run German companies is taking the Bundesbank to court with the charge that the accumulation of German Target2 balances represent embezzlement of funds (Eurointelligence, April 18, 2012)
} 
problem. Section five develops and tests an empirical of the determinants of sovereign yield spreads in the euro area. The critical result is that fiscal fragility and external imbalances explain a significant share of the widening spreads in the euro area since the onset of the global financial crisis. Differences in labor productivity and growth rates between the North and the South have also assumed a more important role since the Greek crisis erupted in 2010. Conclusions are drawn in the last section.

\section{Stylized Facts}

In this section we present some stylized facts of the sovereign debt crisis. We start with an examination of the yields on 10-year government bonds of Greece, Ireland, Portugal, Spain, and Italy (referred to collectively as GIPSIs) and Germany from 2007 to the end of March 2012; left panel of Figure 1. At the time that the European interbank liquidity crisis exploded (7 August, 2007), the GIPSI sovereign yields were very close to Germany's: Ireland and Spain had yield differentials relative to Germany of 9 basis points (bp); Portugal $23 \mathrm{bp}$; Italy 28 and Greece 30. When Lehman filed for bankruptcy protection on September 18, 2008, those spreads had risen to a minimum of $47 \mathrm{bp}$ for Spain, and a maximum of $81 \mathrm{bp}$ for Greece. When severe irregularities in Greek government budget accounting were revealed in January of 2010, the Greek spreads had moved to $271 \mathrm{bp}$; Ireland followed with $156 \mathrm{bp}$; Spain's were lowest at $71 \mathrm{bp}$. From then on these spreads marched relentlessly upward, apparently immune to announcements or actions taken by European Union leaders to contain the crisis.

The spreads peaked at different times: the first to peak was Ireland on July 18, 2011 (1323 bp), then Italy on November 9, 2011 (542 bp), Spain on November 22, 2011 (543 bp), Portugal on January 31, 2012 (1576 bp), and finally Greece on February 28, 2012 (3399 bp). The two long-term refinancing operations by the ECB the first on December 26, 2011 for $€ 486$ billion and the second on February 29, 2012 for $€ 530$ billion are widely believed to have helped the decline in spreads that has taken place from those peaks all the way down to the end of our sample period. The last trading data on Greek bonds is February 29, 2012. Greece averted default after a large majority of private creditors agreed to a large debt haircut on March 9, 2012.

The extraordinary rise in GIPSI's bond yields stands in sharp contrast to the decline of US, UK, and Japanese bond yields - right panel of Figure 1 - as well as to 
German bonds. The German yield declines steadily from its high point of 4.7 percent reached in the middle of 2008 down to 1.8 percent at the end of March, 2012. US and UK yields drop from around 5 percent in 2007, to approximately 2 percent in the first quarter of 2012; Japanese yields drop from the 2 to the 1 percent range over the same period. These are dramatic contrasts that this paper needs to explain.

Differences in inflation expectations, or an expected exchange rate depreciation of the euro relative to the dollar, are not likely explanations of the phenomenon in question. If they were, one would have observed significant differences between the German yields and the US, UK and Japanese yields. In fact, the differences of the German yields from UK and US yields are negligible, while the difference with respect to the Japanese yields is in the order of one percentage point.

High and rising levels of government debt in relation to GDP, and large government budget deficits are a second possible explanation. Table 1 plots the government gross-debt-to-GDP ratios for 11 EA countries and the three outside countries, the United Kingdom, the Unites States, and Japan. Reported data are for 1999 (start of the euro), 2007 (pre-crisis period), 2011, and the first difference between 2007 and 1999 and 2011 and 2007. By 2007, Austria, Belgium, Finland, Ireland, Italy, the Netherlands, and Spain had reduced their debt ratios relative to 1999 values. By contrast, Japan had increased its debt ratio by 54 percentage points and the US by one percentage point. Government financed rescue plans of the banking system and the recession following the financial crisis then raised debt ratios significantly. Particularly hard were hit Ireland (whose debt ratio went up by 89 percentage points), Greece (60 percentage points), Portugal (38), and Spain (31). Japanese, US and UK debt ratios also went up sharply, by 45, 38 and 37 percentage points respectively. In contrast, Italian debt ratio was less influenced by the financial crisis. As of 2011, the EA Southern countries, with the exclusion of Spain, had higher debt ratios than the Northern countries but considerably lower than Japan's.

Next, consider fiscal discipline as measured by the ratio of government primary surpluses to GDP. Figure 2 plots this variable as the cumulative flow over the period 1999 through 2012 (2012 values are IMF forecasts) for the 11 EA countries plus the UK, US, and Japan. Three of the Southern economies accumulated primary deficits, yet less than in France and Ireland. Italy, on the other hand, has accumulated primary surpluses larger than those in Germany and the Netherlands. And the three external 
countries are by far the least fiscally disciplined in that group. Initial debt conditions also matter. A large debt requires larger primary surpluses to offset interest payments on that debt; this is the case of Belgium and Italy. On the other hand, countries with a more virtuous fiscal past are in a position to run larger primary deficits or the same primary surpluses at lesser cost than countries with a profligate past; this is the case in France, Ireland, Spain, the United Kingdom and the United States. The United States, in particular, benefits from the additional advantage that the US dollar is a dominant world currency which makes borrowing cheaper. The puzzle is Japan, a country with an extremely high initial debt-to-GDP ratio (in 1999), and high budget deficits, but no speculative attacks. The fact that Japan has large net foreign assets, continues to run current account surpluses, and has a central bank that, unlike the ECB in the euro area, is willing to be a lender of last resort to government may explain the puzzle.

A third explanation of the heterogeneous effect of public debt on government yields may stem from the composition of public debt. Contrary to what happened in developing countries, the share of foreign currency denominates in several European countries between 1999 and 2007 (Table 1, last two columns). By contrast, the UK, the US, Japan and Germany had virtually all government debt denominated in local currency, reducing the exposure to valuation effects due to exchange rate fluctuations. By contrast, foreign currency debt (a proxy for foreign-held debt) increases macroeconomic volatility and risk since it reduces a country's ability to implement countercyclical policies. Figure 3 illustrates this point by plotting shares of foreign currency denominated debt in 2007 and average yields on 10-year government bonds between 2008 and $2011 .^{5}$ The two variables are positively correlated, with the exception of Finland, at least up to a certain threshold for the share of foreign currency debt.

The final set of stylized fact refers to external imbalances. Table 2 shows for the 11 EA countries cumulative current-account balances as a percent of GDP over the period 1999-2012 (2012 values are IMF forecasts). Note the big divide between the surpluses in the North - Netherlands, Finland, Germany, Belgium, Austria - and the deficits in the South - Italy, Spain, Portugal and Greece - with France acting as median. The table also has two additional columns: the cumulative percentage change

\footnotetext{
${ }^{5}$ Data on the currency composition of public debt are from Panizza and Presbitero (2012), but they extend only to 2008. Hence, we choose to show the correlation between the currency composition of public debt before the onset of the crisis and the subsequent yields in the crisis period.
} 
in unit labor costs for the 1999-2010 period, and the cumulative percentage change in the CPI for 1999-2010. With the exception of Ireland, badly affected by the financial crisis, the North has benefited from low unit labor cost growth and below median inflation rates (i.e. real exchange rate depreciations relative to the South), whereas the South has suffered from high unit labor cost growth and above median inflation rates (real exchange rate appreciation relative to the North). These data are consistent with the hypothesis that the asymmetry in the external imbalances of euro area countries are driven, among other things, by wage and labor productivity differentials which have not been compensated by real exchange rate adjustments.

In sum, the stylized facts raise some doubt about the validity that the sovereign debt crisis has been driven primarily by the lack of fiscal discipline of the South. In fact, to select the problem economies by size of deficit or debt ratios is to pick out the wrong set of countries.

\section{Two Interpretations}

There are at least two interpretations of the sovereign debt crisis in the South of the euro area. The first is the lack of fiscal discipline; the second is the external imbalance and inadequate adjustment mechanisms operating in the EA. The two interpretations are not mutually exclusive; more on this below.

The first hypothesis takes its initial impetus from the financial crisis of 20082009, which instigated a big increase in general risk aversion. It is based on a large literature stressing the adverse role of fiscal deficits and government debt on sovereign bond yields; Baldacci and Kumar (2010), Maltritz (2012) and references cited therein. Fiscal variables have been found to be statistically significant in explaining the rise in government bond yields in the first phase of the financial crisis (Attinasi et al 2009; von Hagen et al. 2011). However, their economic relevance is quite limited. Attinasi et al. (2009), for example, show that fiscal fundamentals explain about the 20 percent of the actual increase in bond yield spreads between July 2008 and March 2009. An additional, smaller role is played by liquidity effects and by the announcement of bank rescue packages, while international risk aversion played the biggest role in explaining the increase in spreads. Interestingly, international risk aversion matters most for the countries with weaker fiscal positions. This result is confirmed by Favero and Missale (2012), who demonstrate that countries with weaker 
fiscal policies have been more exposed to change in global risk, while default risk has been less responsive to global conditions in countries with sounder fiscal positions. However, while this evidence suggests that other variables could be at play, e.g., a higher degree of risk aversion, the question is why would they act exclusively on the South and not on high-deficit, high-debt countries, such as Japan, the United States and the United Kingdom?

The answer comes from the alternative interpretation of the crisis. The shock of the financial crisis has exposed the fragility of the EA construction, which does not permit the South, burdened with external imbalances and rigid economies, to benefit from the fiscal equalization and bail-out commitments normally available to subnational governments of currency unions that are also fiscal unions. It is quite likely that the South may be too big to bail, an issue that does not apply to a country like Japan, for example, whose government is not too big to bail because it has a central bank willing to act as a lender of last resort. Under flexible or adjustable exchange rates, adjustments to a current account deficit occur via a combination of income and exchange rate changes. Under fixed exchange rates, the adjustment occurs by a flow of money from deficit to surplus countries and subsequent price and income adjustments. Should the central bank counteract this money flow with sterilization policies, a speculative attack will induce deficit countries to devalue and surplus countries to revalue their nominal exchange rates. In a monetary union like the Eurozone, NCBs can neither adopt sterilization policies nor adjust their nominal exchange rates. This does not imply, as we have seen, that the monetary union is immune from the risk of a speculative attack induced by persistent external imbalances in some of its member countries. To avoid such a risk, the adjustment to external imbalances must occur through internal revaluation in the surplus countries and/or internal devaluation of the deficit countries. In the EA, this means that the North must have higher incomes, prices and wages; or the South has to have lower incomes, prices and wages; or a combination of the two. This adjustment burden needs to be shared between surplus and deficit countries, with the predominant share of the burden falling on surplus countries when economic activity is slack and on deficit countries in an inflationary environment (Keynes 1943: 20; Mundell 1968, ch. 13). But the North is not willing to reflate. Instead, it has imposed an internal devaluation on the South through a policy of fiscal austerity. Given that internal 
devaluation is difficult and takes a long time to implement, the market expresses its "fears" on the feasibility and sustainability of this strategy by raising risk premia on Southern government debt. These fears are further reinforced by the controversy over the Target 2 balances.

Somewhat belatedly, the literature is beginning to recognize the importance of external imbalances in explaining the euro crisis. ${ }^{6}$ For example, Higgins and Klitgaard (2010:1) rightly note that "countries most affected by the euro area sovereign debt crisis had engaged in substantial foreign borrowing for a number of years." The fall in interest rates following the monetary union membership fueled foreign borrowing by both the public and private sectors in the peripheral countries. However, contrary to the prediction of the Blanchard and Giavazzi (2002) model, “foreign capital was used to support domestic consumption or housing booms rather than productivity enhanceing investments" (Higgins and Klitgaard 2010:1), spreading the seeds of a future sovereign debt crisis. This is the point originally made by Ingram (1973) and further discussed by Giavazzi and Spaventa (2010), who develop a simple model to show that the intertemporal budget constraint influences capital allocation even within a monetary union. A boom of foreign financing directed to the non-tradable residential sector, or to consumption, makes growth unsustainable since the solvency conditions cannot be met. In a similar vein, Waysand et al. (2010:4) state that: "The perception that growing external imbalances could be the reflection of internal unsustainable developments even in the Euro area, with the building up of an excessive indebtedness of private or public agents likely to result in painful adjustment periods, nevertheless gained ground over time.” Merler and Pisani-Ferry (2012:12) state that "conventional wisdom in research and policy was that among euro-area countries, balance-of-payments would become as irrelevant as among regions within a country. Yet developments since 2009 have challenged the wisdom of this view." The CESifo Institute has published a special issue on The European balance of payments crisis (Werner 2012). In his opening sentence, the editor of the issue states: "The European Monetary Union is currently experiencing a serious internal balance of payments

\footnotetext{
${ }^{6}$ Notable exceptions, from different methodological approaches, are Blanchard (2006; 2007) and Brancaccio (2008), who stress the role of balance-of-payments disequilibria and productivity differentials as root causes of the future Eurozone crisis.
} 
crisis that is similar, in many important ways, to the crisis of the Bretton Woods System in the years prior to its demise." 7

On the empirical side, the Bayesian approach followed by Maltritz (2011) points out the importance of the trade balance in explaining the yield spreads in the EMU. Barrios et al. (2009) illustrate the role of current account imbalances in the EA sovereign debt market between 2005 and 2009 and find that their impact on spreads, like for fiscal factors, has been quite limited, if compared to impact of liquidity effects and global risk aversion.

In the following two sections we present a small model showing that these two alternative hypotheses are not mutually exclusive, and then some econometric results on the relative importance of fiscal fragility and external imbalances in explaining the broadening sovereign bond yields in the EA.

\section{A General Framework}

The objective of this section is to present a simple model that demonstrates how poor fundamentals can create a debt problem with or without fiscal responsibility.

The point of departure for this model is the fundamental identity in any open economy: $\mathrm{S}-\mathrm{I}=\mathrm{DEF}+\mathrm{CA}$, where $\mathrm{S}=$ private saving, $\mathrm{I}=$ fixed investments, $\mathrm{DEF}=$ government budget deficit and $\mathrm{CA}=$ current account balance. This identity links external imbalances and private financing imbalances to the government's fiscal imbalance. It shows how imbalances on the right hand side can lead to a banking crisis in the private sector; and/or how an external imbalance, even in the absence of fiscal irresponsibility, can lead to an accumulation of public debt, capital outflows and a financial sector liquidity crisis, in which private debt is replaced by public debt.

For example, if a current-account deficit appears for any reason $(\mathrm{CA}<0)$, then either the government has to run a budget deficit (DEF $>0$ ), or private savings must fall relative to investment $(\mathrm{S}-\mathrm{I}<0)$ to restore equilibrium in the economy. But since private saving tends to rise and investment tends to fall in a recession $(S-I>0)$, the likely outcome is that the government budget deficit rises. In fact, if the private sector

\footnotetext{
${ }^{7}$ Martin Wolf, in the Financial Times of April 10, 2012, titles his articles "Why the Bundesbank is wrong" and declares: Arguably, the crucial step is to agree on the nature of illness. On this, progress is now achieved, at least among economists. It is widely accepted that the balance of payments is fundamental to any understanding of the present crisis."
} 
is carrying too much debt, it will be the first to deleverage in a downturn - creating a banking crisis because savings rise to reduce that debt. This causes a loss of liquidity in the banking system and a potential banking crisis, which leads to even larger fiscal deficits to rebalance economic activity and to replace savings in banks. At that point, excess private debt becomes excess public debt. Demand for assets/bonds in problem countries will collapse, especially in a currency union like the EA where asset sales can be sent to low-risk countries [Germany, Finland, or the Netherlands] without cost or exchange rate risk. Government bonds in the problem countries are then no longer capital risk free, especially if a bailout looks unlikely or too small.

This sequence of events provides the links by which poor macroeconomic fundamentals and current account deficits can easily translate into fiscal deficits and a crisis in the banking sector, even if there has been no fiscal irresponsibility (Ireland, Spain). Fiscal irresponsibility (Greece) simply adds to the fiscal deficits already implied. It is therefore sufficient to model these links for a given fiscal program, responsible or not. The key point is to show how they can cause unsustainable buildups in sovereign or private debt.

Since both current accounts and portfolio balances affect exchange rates and rates of return, and are affected by them, they need to be modeled jointly. This is usually accomplished by assuming perfectly substitutable assets between countries and instantaneous but complete market adjustments. Uncovered interest rate parity can then be applied. However, given that we are dealing with a case where a country's net debt may become excessive, and may have to be curtailed, this approach is not suitable in a world of global imbalances and market distortions caused by sticky prices, fixed exchange rates, sudden stops, and a revealed preference for holding foreign reserves or foreign assets (i.e. safe haven or flight-to-quality effects). A more general approach is provided by Blanchard, Giavazzi and Sa (2005), who build upon earlier models by Masson (1981), Henderson and Rogoff (1983), and Kouri (1983). Blanchard et al. model current account and portfolio balances directly, and the adjustments between them. Their framework permits us to consider imperfect asset substitutability, and hence different asset preferences. It also allows us to examine the stability of the adjustment process in assets/debt under a common currency, sticky relative prices, and sudden stops in capital flows or inter-economy financing. The 
model has been extended by Hughes Hallett and Martinez Oliva (2012) to show the asset positions of different countries and valuation effects caused by financial flows. ${ }^{8}$

The formal model is presented and analyzed in the Appendix. Here we limit ourselves to a description of its main features and its implications. Our simple model considers two countries, home and foreign, linked to each other by an uncovered interest parity condition, current and expected real exchange rates (defined as the price of home goods relative to foreign goods). In the Eurozone, nominal exchange rates are fixed and changes in real exchange rates occur only through relative price levels. A country accumulates net foreign debt through interest payments on the beginning-of-the period debt and a new external imbalance flow, the latter a function of the real exchange rate and trade shocks. Investors' wealth is the difference between domestic assets and net foreign debt; the distribution of wealth between domestic and foreign assets is determined by interest rates and real exchange rates.

In equilibrium, there is a negative relationship between the real exchange rate and net debt in both the portfolio-balance relation and the current-account balance relation. A higher net foreign debt requires a lower exchange rate because the demand for domestic assets has fallen and a larger external surplus is needed to meet interest payments. To ensure stability in both the trade and capital markets, the sensitivity of the real exchange rate $(E)$ to changes in net foreign debt $(F)$ must be higher in the portfolio balance $(P B=0)$ relation than in the current account balance $(C A=0)$; see Figure 4.

The same figure could be used to distinguish differences in adjustments between the EA countries and outsiders like the United Kingdom and the United States, which can use their nominal exchange rates and lender-of-last-resort facility to make the current account sensitive to the real exchange rate. Two specific problems have therefore made the debt crisis in Europe more difficult to resolve: fixed nominal exchange rates (a consequence of currency union membership) and sudden stops in financing. The figure imposes these restrictions with either a fixed real exchange rate $\bar{E}$, or a fixed level of net foreign debt $\bar{F}$ at the left hand vertical line. A fixed real exchange rate shows what will happen with inflexible prices/wages when nominal exchange rates are fixed; $\bar{F}$ what happens if there is a sudden financing stop.

\footnotetext{
${ }^{8}$ Valuation effects appear in Obstfeld (2004), Lane and Milesi-Ferretti (2004), and Gourinchas and Rey (2005).
} 
We start with a fixed exchange rate regime. At a point A, home's current account is in deficit and her net foreign debt is increasing. So the $P B=0$ line shifts to the right, and will continue to do so as long as the fixed exchange rate remains in place and relative prices remain sticky. The process of adjustment goes through an early stage of net foreign debt changes before valuation and exchange rate effects lead to a slide down the $P B=0$ line. But one never gets as far as A'" in the absence of real exchange rate depreciations. The process is not sustainable because home's debt increases without limit; default will eventually break the real exchange rate when the debt ratio can no longer be serviced, the economy goes into recession and prices fall. When that happens, the economy adjusts down the $P B=0$ line until reaches $\mathrm{C}$. But the longer $\mathrm{E}$ is maintained, the further the $\mathrm{PB}=0$ line will have shifted, the greater the debt burden, the bigger the bust. To avoid these outcomes, home or foreign will have to bring a sudden capital stop and provide liquidity support; or they will have to adjust their real exchange rates; or foreign must accept an ever increasing accumulation of claims on home, such as unused foreign assets or Target 2 promissory notes. In sum, debt is the main equilibrating force until countries are forced to adjust the real exchange rate and competitiveness.

We move next to a flexible exchange rate regime. At $\mathrm{B}$, home's current account is in deficit and her net foreign debt is increasing. A saddle path to a new equilibrium is determined by the interplay of a faster adjusting debt, and hence upward pressure on the current account deficit; and a slower adjusting trade balance, hence downward pressure on the current-account deficit. If the former dominates, one does not get back to the $C A=0$ line; instead one moves down a parallel line above it until one gets close to the $\mathrm{PB}=0$ line (assuming that the slower moving trade adjustments allows to catch up with movements in the portfolio balance). Eventually at $P B=0, F$ will be moving slower than the trade balance and it becomes possible to slide down the portfolio balance line to the new equilibrium at $\mathrm{C}$. If the trade balance is sensitive to the exchange rate (i.e., the Marshall-Lerner conditions are satisfied), the pressure to move down to the current account line will be large relative to the changes in debt and we will catch up with the shifts in C. However, the Marshall-Lerner conditions are often not satisfied, especially in the short run when J-curve effects are operative. In the long term, the trade deficit may become sufficiently sensitive to real exchange rate depreciations the economy to approach the $C A=0$ line. If so, $E$ will 
jump to the saddle path and settle at $\mathrm{C}$ where $\dot{F}=0$ and $P B=0$ stops moving. In sum, the danger is that corrections to trade imbalances may never be large enough, rapid enough, or strong enough to balance the current account and stop the debt escalation.

\subsection{Implications}

The model sketched above has several implications for the empirical work that follows. First, both interpretations of the debt crisis - fiscal irresponsibility and external imbalances - are not mutually exclusive and yield comparable implications, especially in the short run.

In the long run, however, the external imbalance interpretation has more explanatory power: factors such as losses of competitiveness, sticky real exchange rates, persistent trade deficits, sudden stops in capital flows, and vanishing liquidity can account for a debt crisis independently of fiscal irresponsibility; whereas irresponsible fiscal policies can be overcome when the fundamentals are strong (e.g., the pre-2005 period). Second, debt sustainability requires higher debt levels to be matched by depreciating real exchange rates; and that the indicators of debt sustainability, such as yields on government securities relative to a safe asset, are more sensitive to portfolio factors and financing flows than to the trade balance.

Third, the relative speeds of adjustments in asset portfolios and trade deficits play a critical role in the debt crisis: debt adjustment (or debt indicators) should react stronger and faster to the level of debt than to current-account deficits (or their underlying determinants). Fourth, whether we can reach an equilibrium position with sticky real exchange rates and financing stops is an empirical matter. The model shows that the longer the fundamentals remain out of balance, the larger are the crash and the adjustment process in the end. Lastly, the loss of market liquidity (a sudden stop in $F$, which manifests itself in larger bid-ask spreads in the securities market) and inflexible real exchange rates render adjustment to a new equilibrium much more difficult, if not impossible.

In the next section, we will test some of the implications of the two interpretations of the debt crisis. 


\section{The determinants of EMU sovereign yield spreads}

\subsection{The empirical model}

To assess the relative importance of external imbalances and fiscal variables on the evolution of the 10-year government bond spreads relative to German bunds (Spread), we follow the recent literature on European sovereign debt crisis (Codogno et al. 2003; Pagano and von Thadden 2004; Barrios et al. 2009; von Hagen et al. 2011; Maltritz 2012; Favero and Missale 2012) and estimate a simple model based on quarterly data for 10 euro-area countries. ${ }^{9}$ In particular, Spread is modeled as a function of variables capturing global, regional and country-specific conditions:

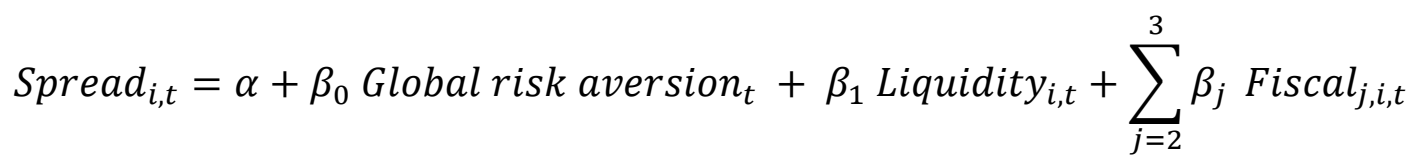

$$
\begin{aligned}
& +\sum_{j=4}^{7} \beta_{j} \text { Imbalances }_{j, i, t}+\eta_{i}+\epsilon_{i, t}
\end{aligned}
$$

where $i$ refers to the $i$-th EA country and $t$ refers to the quarter. Consistently with the majority of the recent literature on EA spreads, all country-specific explanatory variables are measured as differences from the benchmark German values (von Hagen et al. 2011; Maltritz 2012; Favero and Missale 2012). In view of the noted empirical importance of aggregate risk in explaining yield differentials (Codogno et al. 2003; Geyer et al. 2004; Favero et al. 2010), we use a synthetic measure of general risk aversion (Global Risk Aversion). We construct this variable from the first principal component of four alternative indicators of global riskiness: the volatility index of the OEX market, the effective long-term yields on AAA- and BBB-corporate bonds and the yields and volatility index on US-euro and euro-yen 3-month exchange rate (as in Barrios et al. 2009). The Principal Component Analysis shows that the four indicators are highly correlated. The first component (our Global Risk Aversion) explains 62 per cent of the variance in the data and is constructed to give the same weights to each of the four underlying variables. Figure 5 shows the evolution of Global Risk Aversion and a synthetic index of the 10 EA Spreads, computed as the first component of the

\footnotetext{
${ }^{9}$ As standard in this literature, we drop the other EMU countries from the sample as being too small.
} 
individual Spreads (identified in the figure as Sovereign Risk Factor). ${ }^{10}$ Note that the two variables are highly and positively correlated up until the first phase of the financial crisis; but they start to diverge in 2010 after the downgrade of Greece's credit rating in December 2009, which in turn triggered massive capital outflows and sudden-stop episodes in the EA South (Merler and Pisani-Ferry 2012). ${ }^{11}$ This steep increase in EA sovereign bond yields in a period of a stable (or moderately declining) global risk aversion is consistent with the hypothesis that the sovereign debt crisis is EA-specific and has causes which go beyond raw fiscal profligacy.

Our empirical model includes Liquidity, a measure of liquidity risk in the bond markets. This effect has been recognized by the literature in general (e.g., Amihud and Mendelson 2006; De Nicolò and Ivaschenko 2009) and with respect to EA sovereign spreads in particular (e.g., Attinasi et al. 2009; Barrios et al. 2009). ${ }^{12} \mathrm{We}$ measure liquidity conditions using bid-ask spreads on the secondary markets for 10year government bonds. Figure 6 plots this measure of liquidity as the bid-ask spread with the opposite sign. It reveals a severe liquidity contraction in the Greek market, where the bid-ask spread rose to above $700 \mathrm{bp}$; and, to a lesser extent, in the Irish and Portuguese markets in 2011. Italy and Spain, by contrast, experienced very moderate increases in bid-ask spreads (16 bp and $11 \mathrm{bp}$, respectively), almost the same as those observed in Austria and Belgium. By contrast, the German market remained deep and liquid throughout the sovereign debt crisis.

The role of fiscal variables in driving Spreads is documented, among others, by Attinasi et al. (2009) and von Hagen et al. (2011). Our vector Fiscal consists of two variables: primary-budget-balance-to-GDP ratio and gross-government-debt-toGDP ratio, both measured as differentials from the German counterparts. These ratios are widely recognized as indicators of fiscal fragility and have received maximum attention from policy makers. ${ }^{13}$ Larger budget deficits are perceived as indicators of a

\footnotetext{
${ }^{10}$ In this case, the first principle component (the Sovereign Risk Factor variable) explains 82 percent of the variance of 10-country spreads.

${ }^{11}$ The correlation between the two variables is 0.88 between January 1999 and August 2008, declines to 0.50 between September 2008 and December 2009 and further to -0.55 between January 2010 and March 2012.

12 The role of liquidity in EMU bond markets emerged during the crisis, having been quite small and interwined with fundamental risk during tranquil periods (Geyer et al. 2004; Pagano and von Thadden 2004; Favero et al. 2010).

${ }^{13}$ See the VoxEU debate started by Corsetti (2012). Empirically, the two fiscal measures are highly correlated with spreads (Maltritz 2012; Favero and Missale 2012).
} 
lax fiscal policy, and hence default risk to the extent that they undermine public debt sustainability. Debt sustainability is also weakened by high values of existing public debt: small changes in interest rates exert large changes in interest payments on debt. Therefore, financial markets start demanding higher risk premia when public debts are perceived to be "too high." The emergence of higher risk premia may, in turn, trigger a vicious cycle of rising interest expenditures and growth-reducing fiscal austerity undertaken during periods of slow or negative economic growth (Perotti 2012).

We have shown that some countries in the South - e.g., Spain - had better fiscal positions than Germany before the onset of the crisis and have argued that the roots of the crisis are deeper than fiscal profligacy. Our focus has been on external imbalances instead and the fragility of the EA in the absence of a smooth adjustment mechanism for resolving these imbalances (see Section 3 above). The vector Imbalances in our empirical equation includes explanatory variables that address this external imbalance issue; namely, real GDP growth (Growth), changes in the general level of prices (Inflation), growth of labor productivity (Labor productivity), and trade balance as a per cent of GDP (Trade balance). Finally, $\eta_{i}$ are country fixed effects and $\varepsilon_{i t}$ is the error term. Table 3 reports the variable definitions, data sources and sample means.

The model is estimated using a Panel-corrected standard error (PCSE) estimator based on quarterly data from 2000:q1 to 2011:q2. The PCSE estimator assumes that the disturbances are heteroskedastic and contemporaneously correlated across panels and that, within panels, there is first-order autocorrelation where the coefficient of the AR(1) process is specific to each panel. Moreover, in this context the PCSE estimator is preferable to Feasible General Least Squares (FGLS) because the latter generates over-optimistic variance-covariance estimates in panels with a limited time dimension (Beck and Katz 1995). ${ }^{14}$

\footnotetext{
${ }^{14}$ For an application of PCSE to a similar model but in a slightly different context, see Barrios et al (2009) or Schimtz and von Hagen (2010). The small number of observations and, especially, the limited number of countries prevents us from using a more complete dynamic specification and GMM estimates (Arellano and Bond 1991), which are unsuited to samples like ours (Bond 2002). Our main results, however, are confirmed using a standard fixed effect model and other estimators used to model the autocorrelation of the residuals. Results are also robust to the inclusion of the lagged dependent variable to take into account its high persistence.
} 


\subsection{Main results}

Table 4 summarizes the main results of the estimates of the empirical equation. The basic specification (column 1) suggests that the degree of global risk aversion does not affect EA yield spreads. They are, instead, influenced by market liquidity, fiscal fragility and macroeconomic fundamentals. A deterioration of the fiscal position and a contraction in market liquidity, relative to the German anchor, spill over into higher spreads. Spreads also rise when economic growth slows down, or labor productivity declines and inflation rises, all relative to Germany. These findings are consistent with the hypothesis that external imbalances contribute to explaining the crisis. Column 2 of the table then adds external imbalances explicitly, as proxied by trade balance. However, trade balance is not statistically significant. One reason for this is that the trade balance-or current account balances for that matter-may not be a good measure of capital flows across the euro area; more on this below. Next column 3 controls for possible political-risk effects, proxied here by the International Country Risk Guide (ICRG) index, on sovereign yield spreads. The Political risk coefficient does not indicate that factors such as government stability, level of corruption or bureaucratic quality have any influence on spreads, once macroeconomic fundamentals and country-specific fixed effects are controlled for.

In columns 4 and 5, we expand the model to include a unit dummy for the period after December 31, 2009 (Post 2010) and its interaction with a unit dummy for Greece (Greece), and with another unit dummy for Portugal, Ireland, Italy and Spain (PIIS). ${ }^{15}$ The motivation for this is to capture the steep spike in the Southern spreads since 2010, which might not be properly reflected in the model's other determinants. These additions however do not weaken the statistical significance of the coefficients of the fiscal and macroeconomic variables, or of the bid-ask spread. But for a few variables, notably Growth, the coefficient size is reduced. Also, with this augmented specification, we observe that the coefficient of Global Risk Aversion turns positive and statistically significant, suggesting that the correlation between sovereign risk and the overall risk aversion is positive in normal times (see Figure 5). Finally, column 5

\footnotetext{
${ }^{15}$ To save degrees of freedom, we do not include the interaction terms between the Post 2010 dummy and the four dummies for Portugal, Ireland, Italy and Spain separately in columns 4 and 5, since the increase in the spread in those countries after 2010 are quite homogeneous and much smaller than in Greece. However, results are robust to the inclusion of separate interaction terms. Results not reported to save space, but are available upon request.
} 
includes all variables: it confirms the importance of fiscal and external imbalances, even if trade balance is not statistically correlated with spreads.

So far, we have not been able to explicitly control for the role of capital flows within the Euro-zone. An interpretation of the European debt crisis in terms of foreign borrowing and lending imbalances is gaining momentum (Higgins and Klitgaard 2010; Sinn 2010; Giavazzi and Spaventa 2010; Merler and Pisani-Ferry 2012; EEAG 2012). Specifically, large foreign bank lending from the North to the South before the crisis, sudden capital reversals in the wake of the crisis, and mounting NCB Target 2 balances give us a much more accurate picture of diverging external imbalances than the current account balance (Buiter et al. 2011). Take, for example, foreign lending by German banks to EA countries. It shows a steep increase in lending to Spain, Ireland and Portugal up to the first months of 2008. In Ireland, Portugal, and Spain, foreign capital was mainly channeled to non-tradable sectors like housing, making the intertemporal budget constraint unsustainable (Giavazzi and Spaventa 2010, Lane and Pels 2012). Then, once the Greek crisis started, solvency fears and uncertainty about liquidity provisions by the ECB triggered a crisis of confidence and a sudden capital reversal in the Southern countries (Merler and Pisani-Ferry 2012). Figure 7 shows a negative correlation between foreign borrowing and sovereign yield spreads in Southern countries, suggesting a nexus between bank lending and the EA debt crisis.

Next, we add to our empirical model a country-specific measure of foreign bank lending: the ratio of a country's financial liabilities vis-à-vis German banks to its GDP (Liabilities to German banks), as reported in the consolidated banking statistics of the Bank of International Settlements (2012). These data are available only since 2005; so we re-estimate the first two columns of Table 4 over the shorter sub-sample using our measure of foreign borrowing. Results are reported in Table 5. The presence of Liabilities to German banks does not alter the effect of the main variables of the model on spread (column 1); nor does it make the coefficient of Trade balance statistically significant (column 2). Instead, the Liabilities to German banks coefficient is negative and statistically significant; a result that is consistent with the hypothesis that credit retrenchment is positively associated with a surge in spreads (column 3). This effect is robust, but numerically small, even when we add the Post 2010 dummy and its interaction terms with Greece and PIIS (column 4). 


\subsection{Fiscal fragility, external imbalances, or both?}

The results reported in Tables 4 and 5 justify the attention given to fiscal adjustment to heal the Eurozone debt problems. But the same results also point to a decisive role played by differences in competitiveness and economic growth between the North and the South. To assess which of these two competing, but not necessarily alternative, explanations of the Eurozone crisis matters more, we calculate the contribution of each determinant in explaining the change in Spread using the regression coefficients of columns 3 and 4 of Table 5 and the actual changes in the determinants between 2011:q2 and 2008:q3, and between 2011:q2 and 2010:q1; see Table 6.

Considering the more conservative figures reported in the bottom panel of the table, the statistically significant macroeconomic variables [market liquidity and global risk aversion] explain 45 percent of Spread between the third quarter of 2008 and the second quarter of 2011. This increases to 59 percent in the second part of the crisis, starting in 2010:q1. But taking the periods of the global financial crisis and then the sovereign debt crisis together, the bid-ask spread and public debt are the two main drivers of Spread, accounting for 86 and 46 bp, respectively, out of an average $290 \mathrm{bp}$ increase in spreads across EA countries. If, instead, we focus only on the sovereign debt crisis period, the role of public debt becomes negligible (accounting for an increase in Spread of less than $7 \mathrm{bp}$ ), while labor productivity becomes the other relevant factor, together with market liquidity, in explaining the widening spreads between the Southern countries and Germany.

In sum, the results point to the greater importance of market liquidity in times of uncertainty (as in Beber et al. 2009) and a shift from a fiscal crisis to a balance-ofpayment crisis, which is grounded in labor productivity differences between the North and the South.

\subsection{Testing for structural breaks}

The empirical work so far assumes that the coefficient estimates remain the same over time. However, regression results reported in Table 4 (column 5) and Table 5 (column 4) indicate that the model itself is not able to fully explain the Eurozone crisis since 2010. The Post 2010 dummy and the interaction terms are statistically significant and they greatly increase the R-squared of the regression. Hence, we test for the presence 
of a structural break around 2010. ${ }^{16}$ Table 7 shows the results for the two main specifications, one for the full sample and one for the subsample including foreign borrowing by German banks. In both cases, the Chow test confirms that there is a structural break in the wake of the Eurozone crisis: the effect on the explanatory variables is significantly different across the pre-2010 and the post-2010 samples, as shown by the t-tests on the equality of coefficients.

Specifically, Global Risk Aversion has the standard positive coefficient in the pre-crisis period, but turns negative in the midst of the Eurozone crisis, further confirming the regional dimension of the crisis. On the whole, the role of fiscal variables and external imbalances is magnified during the crisis, while the effect of market liquidity is much lower than in the pre-2010 period, consistent with evidence recently provided by Favero and Missale (2012) on default risk as the main driver of sovereign yields. Finally, it is worth stressing that the effect of differences in the growth of labor productivity and foreign borrowing are significant in the crisis period only, providing additional evidence in favor of the external imbalance interpretation of the sovereign debt crisis.

\section{Conclusions}

This paper has presented two views of the European sovereign debt crisis. The first is that the South of the euro zone has been fiscally irresponsible, and has failed to implement necessary supply-side policies such as liberalizing labor markets and the market for services. This interpretation has won official recognition and represents the prevailing wisdom in the eurozone. It has led to an austerity program aimed at reducing government budget deficits and government debt-to-GDP ratios in the South, haircuts on holders of government debt should member countries receive financial assistance from the European Union or to restructure their public debt, and to a new Fiscal Compact that reinforces the provisions of the existing Stability and Growth Pact.

The second view is that Germany and France, but primarily Germany, have failed to understand the nature of the sovereign debt crisis. Within the Eurozone, the

\footnotetext{
${ }^{16}$ Consistently with our overall approach, the break is set at December 31, 2009. However, results are similar if we anticipate or delay that date by three months.
} 
North has enjoyed large current-account surpluses while the South has accumulated large current-account deficits, suggesting that the euro is too weak for the North and too strong for the South. Since exchange rates are "permanently" fixed within the Eurozone and given that the level of economic activity is historically low in the South, the burden of adjusting external imbalances should fall primarily on the North through an expansion of aggregate demand rather than forcing the South to curtail its demand. The austerity program imposed on the South implies a reduction of income that is bound to counteract the effects of austerity on budget deficits and debt ratios. Furthermore, an important reason for the crisis is that the South cannot benefit from the insurance mechanism that operates in other fiscal unions, which redirects public funds from above-average income regions to below-average income regions. The sovereign debt default mechanism, in fact, reflects the absence of this solidarity, and aggravates the risk of a euro implosion.

These two views are not inconsistent with one another. The first stresses the need for fiscal correction, although not necessarily in the short term. The second recognizes the importance of the long-run fiscal adjustment but identifies the source of the sovereign debt crisis in inadequate adjustments in competiveness and between surplus and deficit countries within the union. As presently constituted, the euro area lacks two important safety valves: the transfer union and an iron-clad guarantee that national central banks have unlimited access to credit in the settlement of intra-euro area payments.

The stylized facts in Section 2, and the model presented in Section 4, raise some doubts about the interpretation that debt crisis is driven only or primarily by fiscal irresponsibility in the South. The comparison of the correlation between debt levels, primary balances and yield spreads in southern European countries and in the UK, US and Japan suggest that fiscal fundamentals alone are not enough to explain sovereign risk. Even within the euro area, some southern countries had sounder fiscal positions than Germany before the onset of the crisis. By contrast, there is a deep divide between the external surpluses of the North and the external deficits of the South. The North has benefited from low unit labor cost growth and a real exchange rate depreciations relative to the South. This trend has been mirrored by capital outflows from the North-especially from German banks-to the South. These flows were used to finance domestic consumption and a boom in the residential 
sector rather than productive investments, spreading the seeds of the sovereign debt crisis.

The empirical analysis of the determinants of government bond yield spreads suggests that both interpretations can provide useful insights on the roots of the current sovereign crisis. Fiscal fragility and external imbalances explain a significant share of the widening spreads since the onset of the global financial crisis. However, differences in labor productivity growth rates between the North and the South assume a more central role since the Greek crisis erupted in 2010. 


\section{APPENDIX: A Model of Current Account and Portfolio Balances}

Consider a home country, say Spain, and foreign country, say Germany (denoted with a “*”), which are linked by the uncovered interest parity condition,

$$
(1+r)=\left(1+r^{*}\right) E / E_{+1}^{e}
$$

where $r$ and $r^{*}$ are the home and foreign rates of interest respectively, $E$ is the real exchange rate (defined as the price of home goods relative to foreign goods), and $E_{+1}^{e}$ is the real exchange rate expected next period. Thus

$$
E=P /\left(e P^{*}\right)
$$

where $e$ is the nominal exchange rate defined as the domestic currency price of foreign currency (e.g., dollars per euro if the US is the home country). In the specific case of Spain and Germany, $e=1$. The home country accumulates net foreign debt according to:

$$
F_{+1}=(1+r) F+D\left(E_{+1}, z_{+1}\right),
$$

where $F$ is the net debt denominated in the home currency (the amount of domestic currency needed to pay them off $)^{17} . D(E, z)$ is the trade deficit, which is a positive function of the real exchange rate. $z$ is a shift variable describing the impact of a trade shock, a change in preference for home goods, or other changes in spending or the pattern of spending on those goods.

To allow for imperfect substitutability between national assets, let $\mathrm{W}$ be the total wealth of home investors, X the total stock of home's assets, and F net debt position of the home economy (all in real terms). Thus:

$$
W=X-F, \quad \text { where } F \geq 0 \text { implies net debt/liabilities }
$$

Wealth of foreign investors, in home's currency, is

$$
W * / E=X * / E+F .
$$

The expected real rate of return from holding home's assets relative to foreign's is

$$
R^{e}=\left[(1+r) /\left(1+r^{*}\right)\right] \cdot E_{+1}^{e} / E .
$$

Home investors place a share $\alpha$ in home securities and 1- $\alpha$ in foreign assets; and $\alpha^{*}$ and $1-\alpha^{*}$ are the corresponding shares of foreign investors. We assume that $\alpha$ is increasing in the relative rates of return on home assets, $R^{e}$, and in $s$, defined as the preference for holding domestic assets including any home bias, and safe haven effects. Symmetrically, $\alpha^{*}$ is decreasing in those two factors. If home biases dominate the asset market, then $\alpha+\alpha^{*}>1$. Equilibrium in the market for home's assets, and hence foreign's assets, is given by the following portfolio balance (PB) equation:

$$
X=\alpha W+\left(1-\alpha^{*}\right) W^{*} / E=\alpha(X-F)+\left(1-\alpha^{*}\right)(X * / E+F) .
$$

Unlike in perfect substitutability, the distribution of wealth between home and foreign is independent of shifts in the trade or current account balances (i.e. $z$ ). Instead the real exchange rate $E$, relative rates of return $R^{e}$, and asset preferences $s$, all of which

\footnotetext{
${ }^{17}$ We do not distinguish home's foreign and domestic held debt since no Eurozone country can use monetary policy to inflate its debt away. In that sense, all debt is "foreign".
} 
affect $\alpha$, determine and are determined by the distribution of wealth holdings. Nevertheless, trade and current account balances do lead to changes in F, and hence to changes in the real exchange rate:

$$
\frac{d E}{d F}=-\frac{\alpha+\alpha^{*}-1}{\left(1-\alpha^{*}\right) X^{*} / E^{2}}<0 \quad \text { iff } \quad \alpha+\alpha^{*}>1
$$

The portfolio balance relation is nonlinear in E-F space and is downward sloping as long as home biases persist $\alpha+\alpha^{*}>1$. Under these conditions, higher debt at home requires a lower exchange rate (because the demand for home assets has fallen, a larger trade surplus is needed to meet interest payments); and real exchange rates respond less to current-account imbalances than to changes in portfolio preferences and the distribution of wealth.

If home and foreign goods are imperfect substitutes, and the trade balance $D$ behaves as in (3), then home's net debt in the next period will be:

$$
\Delta F_{+1}=\left(1-\alpha^{*}\right)(1+r) W * / E-(1-\alpha)\left(1+r^{*}\right) W \cdot E / E_{+1}^{e}+D\left(E_{+1}, z_{+1}\right) .
$$

That is foreign ownership of home assets (plus interest), less the value of home owned foreign assets plus interest, plus the next trade deficit. Rewriting with (4), (5) and (6):

$$
F_{+1}=(1+r) F+(1-\alpha)(1+r)\left(1-1 / R^{e}\right)(X-F)+D_{+1} .
$$

This is the current-account balance (CA) relation since $C A_{+1}=D_{+1}-r F$. The middle term reflects the changing evaluation of home-owned foreign assets due to differing rates of return (including risk premia). Equation (10) contains, not only the CA balance, but also the cumulative effect of "discretionary" trade-balance choices. Policymakers have little control over $F$ except by providing liquidity or loans in the face of sudden stops in capital or financing flows (i.e. when $F$ is held constant), except through future trade balances and growth. The slope of the CA relation, in $E-F$ space in the current period, is:

$$
\frac{d E}{d F}=\frac{-E_{+1}}{(1-\alpha)\left(1+r^{*}\right)(X-F)}<0
$$

which depends on the size of the domestic asset base: a large asset base, $X>F$, means a shallow slope, a small asset base a steep slope. This is the normal state of affairs since, if $F$ rises, it requires $E$ to fall to create a move towards a trade surplus at home in order to generate sufficient extra revenues to pay for the higher net debt - the more so the smaller is the asset base relative to foreign ownership of domestic assets. That implies (11) will have to be negative.

The following condition, that the portfolio balance line is steeper than the CA relation, must be satisfied to ensure stability in both the trade and capital markets:

$$
\frac{(1-\alpha)\left(1-\alpha^{*}\right)}{\alpha+\alpha^{*}-1}>\frac{E_{+1} E^{2}}{\left(1+r^{*}\right) X^{*}(X-F)} .
$$

Equation (12) is satisfied if:

\footnotetext{
${ }^{18}$ Both (8) and (11) are derived assuming that variations in $\alpha$ and $\alpha^{*}$ are small and may be ignored. This is correct up to a first-order approximation. Moreover $\alpha+\alpha^{*}>1$ is a natural condition given trans-actions costs and foreign risks, and that $\alpha, \alpha^{*}=1 / 2$ implies indifference between $X$ and $X^{*}$ as assets.
} 
- $\quad X>F$ or $F<0$. This represents an economy with a large domestic asset base and is self-sufficient in investment and funding; on the contrary, stability is at risk if the economy is heavily dependent on foreign debt for funding.

- If $E$ is low and expected to remain low; or $X^{*}$ is large. This is generally a matter of policy stance; as in Germany in the EA, or China beyond.

- If $\alpha+\alpha^{*} \approx 1$, i.e. if assets are largely substitutable, but $\alpha \alpha *$ is large.

These stability conditions are not met if

- $\quad \alpha+\alpha^{*}<1$

- $X>F$ is sufficiently small even in the presence of $\alpha+\alpha^{*}>1$ and. That is likely in Greece, Portugal and Ireland whose assets are widely held by other EA countries. Italy, whose assets are predominantly held at home, may be relatively safe because $\alpha^{*}$ will be large, even if $\alpha \approx 1 / 2$ for the rest of the Eurozone.

\section{References}

Alessandrini, Pietro, 1989, I flussi finanziari interregionali: interdipendenze funzionali ed indizi empirici sulla realtà italiana, in Niccoli, Alberto (ed.), Credito e sviluppo, Milano: Giuffré editore.

Amihud, Yakov, Mendelson, Haim, 2006, Stock and bond liquidity and its effect on prices and financial policies, Financial Markets and Portfolio Management, 20: 19-32.

Arellano, Manuel, Bond, Stephen R., 1991, Some tests of specification for panel data: Monte Carlo evidence and an application to employment equations, Review of Economic Studies, 58: 277-97.

Attinasi, Maria-Grazia, Checherita, Cristina, Nickel, Christiane, 2009. What explaines the surge in Euro area sovereign spreads during the financial crisis of 2007-2009?, ECB, WP NO 1131.

Baldacci, Emanuele, Kumar, Manmohan S., 2010, Fiscal Deficits, Public Debt, and Sovereign Bond Yields, IMF WP/10/184, August

Bank for International Settelements (BIS), 2012, Guidelines to the international consolidated banking statistics, updated version February.

Barrios, Salvador, Iversen, Per, Lewandowska, Magdalena, Setzer, Ralph, 2009, Determinants of intra-euro area government bond spreads during the financial crisis, European Economy, Economic Papers N. 388.

Beber, Alessandro, Brandt, Michael W., Kavajecz, Kenneth A., 2009, Flight-toQuality or Flight-to-Liquidity? Evidence from the Euro Area Bond Market, Review of Financial Studies, 20: 527-52.

Beck, Nathaniel, Katz, Jonathan N., 1995, What to do (and not to do) with timeseries-cross-section data, American Political Journal Review, 89: 634-47.

Blanchard, Olivier, Giavazzi, Francesco, 2002, Current account deficits in the euro area: The end of the Feldstein-Horioka puzzle?, Brookings Papers on Economic Activity, 2.

Blanchard, Olivier, 2006, Portugal, Italy, Spain and Germany. The implications of a suboptimal currency area, WEL - MIT Meeting, New York, April.

Blanchard, Olivier, 2007, Adjustment within the euro. The difficult case of Portugal, 
Portuguese Economic Journal, 6.

Blanchard, O., F. Giavazzi and F. Sa, 2005 "The US Current Account and the Dollar". Brookings Papers on Economic Activity, 1, 2005, 1-49.

Bond, Stephen R., 2002, Dynamic panel data models: a guide to micro data methods and practice, Portuguese Economic Journal, 1: 141-62.

Borio, Claudio, Disyatat, Piti, 2011, Global imbalances and the financial crisis: Link or no link?, BIS Working Papers No 346, May.

Bornhorst, Fabian, Mody, Ashoka, 2012, TARGET imbalances: Financing the capitalaccount reversal in Europe, VoxEU, 7 March.

Brancaccio, Emiliano, 2008, Deficit commercial, crisi di bilancio e politica deflazionistica, Studi economici, 96 (3)

Buiter, Willem H., Rahbari, Ebrahim, Michels, Juergen, 2011, The implications of intra-euro area imbalances in credit flows, CEPR Policy Insight, No. 57.

Codogno, Lorenzo, Favero, Carlo, Missale, Alessandro, 2003, Yield spreads on EMU government bonds, Economic Policy, October: 503-532.

Corsetti, Giancarlo, 2012, Has austerity gone too far?, VoxEu, 2 April.

De Bonis, Riccardo, Rotondi, Zeno, Savona, Paolo (eds.), 2010, Sviluppo, rischio e conti con l'esterno delle regioni italiane, Edizioni Laterza.

de Grauwe, Paul, 2010, A mechanism of self-destruction of the eurozone, CEPS Commentary, 9 November.

DeLong, Bradford, Summers, Lawrence, 2012, Fiscal policy in a depressed economy, paper presented at the Spring 2012 Brookings Panel.

Delors Report [Committee for the Study of Economic and Monetary Union], 1989, Report on Economic and Monetary Union in the European Community, Luxembourg: Office for Official Publications of the EC.

De Nicolò, Gianni, Ivaschenko, Iryna, 2009, Global liquidity, risk premiums and growth opportunities, IMF working paper, No. 09/52.

Eichengreen, Barry, 1990, One money for Europe? Lessons from the U.S. currency union, Economic Policy 10: 119-186.

European Economic Advisory Group (EEAG), 2012, Report on the European Economy, CESifo 27 February.

Favero, Carlo, Pagano, Marco, von Thadden, Ernst-Ludwig, 2010, How does liquidity affect government bond yields?, Journal of Financial and Quantitative Analysis, 45: 107-34.

Favero, Carlo, Missale, Alessandro, 2012, Sovereign Spreads, Economic Policy, 70: 231-273

Fratianni, Michele, 2012, "The Future International Monetary System: Dominant Currencies or Supranational Money? An Introduction", Open Economies Review 23: 1-12

Fratianni, Michele, von Hagen, Jürgen, 1992, The European Monetary System and European Monetary Union, Westview.

Galli, Giampaolo (ed.), 1990, Il sistema finanziario nel Mezzogiorno, Roma: Banca d'Italia.

Garber, Peter, 1999, The TARGET mechanism: will it propagate or stifle a stage III crisis?, Carnegie-Rochester Conference Series on Public Policy, 51:195-220.

Geyer, Alois, Kossmeier, Stephan, Pichler, Stefen, 2004, Measuring systemic risk in EMU government yield spreads, Review of Finance, 8: 171-97. 
Giavazzi, Francesco, Spaventa, Luigi, 2010, Way the Current Account May Matter in a Monetary Union - Lessons from the Financial Crisis in the Euro Area, CEPR Discussion paper, No. 8008.

Gourinchas, P-O., and H. Rey, 2005, "International Financial Adjustment", mimeo, University of California, Berkeley and Princeton University.

Henderson, D. and K. Rogoff, 1982, "Negative Net Foreign Asset Poitions and Stability in a World Portfolio Balance Model", Journal of International Economics, 13, 85-104.

Higgins, Matthew, Klitgaard, Thomas, 2010, Savings Imbalances and the Euro Area Sovereign Debt Crisis, Current Issues in Economics and Finance, 17(5)

Hughes Hallett, A and J.C. Marinez Oliva, 2012, "Reducing Global Imbalances: Can Fixed Exchange Rates and Current Account Limits Help?", Open Economies Review, 23, 163-92.

International Monetary Fund (IMF), 2012, Fiscal Monitor - Balancing Fiscal Policy Risks, Washington, DC, April.

Ingram, J. C., 1973, The case for European monetary integration, Essays in International Finance N. 98, Princeton University.

Kenen, Peter B., 1969, The theory of optimal currency areas: An eclectic view. In Robert A. Mundell and Alexander K. Swoboda (eds.), Monetary problems of the international economy. Chicago: University of Chicago Press.

Keynes, John Maynard, 1943, Proposals for an international clearing union, British government publication, Cmd. 6437, London (April).

Kouri, P. 1983, "Balance of Payments and the Foreign Exchange Market: a Dynamic Partial Equilibrium Model" in J. Bhandari and B. Putnam (eds) "Economic Inter-dependence and Flexible Exchange Rates", MIT Press, Cambridge, MA.

Krugman, Paul, 2012, Insane in Spain, The New York Times, April 15.

Lane, Philip and Milesi-Ferretti, Gian Maria, 2004 "Financial Globalization and Exchange Rates", Discussion Paper 4745, Centre for Economic Policy Analysis, London.

Lane, Philip and Pels, Barbara, 2012, Current Account Imbalances in Europe, IIIS Discussion Paper, No. 397.

MacDougall Report [Commission of the European Communities], 1977, Report of the Study Group on the Role of Public Finance in European Integration, Vol. I and Vol. II, Brussels.

Maltritz, Dominik, 2012, Determinants of sovereign yield spreads in the Eurozone:A Bayesian approach, Journal of International Money and Finance, 31:657-672.

Masson, P. 1981, "Dynamic Stability of Portfolio Balance Models of the Exchange Rate", Journal of International Economics, 11, 467-477.

McGuire, Patrick, von Peter, Götz, 2009, The US dollar shortage in global banking and the international policy response, BIS Working Papers No 291, October.

Merler, Silvia, Pisani-Ferry, Jen, 2012, Sudden stops in the Euro area, Brueghel Policy Contribution Issue 2012/06.

Milesi-Ferretti, Gian-Maria, Strobbe, Francesco, Tamirisa, Natalia, 2010, Bilateral financial linkages and global imbalances: a view on the eve of the financial crisis, IMF WP/10/257, November.

Milesi-Ferretti, Gian-Maria, Tille, Cedric, 2011, Capital flows and the crisis, Economic Policy, April: 291-346.

Mundell, Robert, 1968, International economics, London, MacMillan

Neumann, Manfred J.M., 2012, Too early to sound the alarm, VoxEu, 17 April. 
Obstfeld, M. (2004), "External Adjustment", Review of World Economics, 140, 541568.

Obstfeld, Maurice, 2012, Financial flows, financial crises, and global imbalances, Journal of International Money and Finance 31: 469-480.

Pagano, Marco, von Thadden, Ernst-Ludwig, 2004, The European bond markets under EMU, Oxford Review of Economic Policy, 20: 531-54.

Panizza, Ugo, Presbitero, Andrea F., 2012, Public debt and economic growth: Is there a causal effect?, MoFiR working paper, No. 65.

Perotti, Roberto, 2012, The "Austerity Myth" Gain Without Pain?, in Fiscal Policy After the Financial Crisis, NBER Chapters.

Sachs, Jeffrey, Sala-i-Martin, Xavier, 1989, Optimum fiscal policy and optimum currency areas, working paper, Harvard University.

Schuknecht, Ludger, von Hagen, Jürgen, Wolswijk, Guido, 2009, Government risk premiums in the bond market: EMU and Canada, European Journal of Political Economy, 25: 371-384.

Schmitz, Birgid, von Hagen, Jurgen, 2010, Current account imbalances and financial integration in the euro area, Journal of International Money and Finance, 30: 1676-95

Sinn, Hans-Werner, 2010, Rescuing Europe, CESifo Forum, August.

Sinn, Hans-Werner, Wollmershäuser, T., 2011, Target loans, current account balances and capital flows: The ECB's rescue facility, CESifo WP N. 3500, 21 June.

Sinn, Hans-Werner (ed.), 2012, The European balance of payments crisis, CESifo Forum, January.

Tamagna, Frank M., Qualeatti, Daniele, 1978, Sviluppo economico e intermediazione finanziaria, Milano: Franco Angeli.

von Hagen, Jurgen, Schuknecht, Ludger, Wolswijk, Guido, 2011, Government bond risk premiums in the EU revised: The impact of the financial crisis, European Journal of Political Economy, 27: 36-43.

Waysand, Claire, Ross, Kevin, de Guzman, John, 2010, European financial linkages: a new look at imbalances, IMF WP/10/295, December.

Wolf, Martin, 2012, Why the Bundesbank is wrong, Financial Times, April 10. 
Figure 1: Yields on 10-year government bonds, daily observations 2007-March 2012
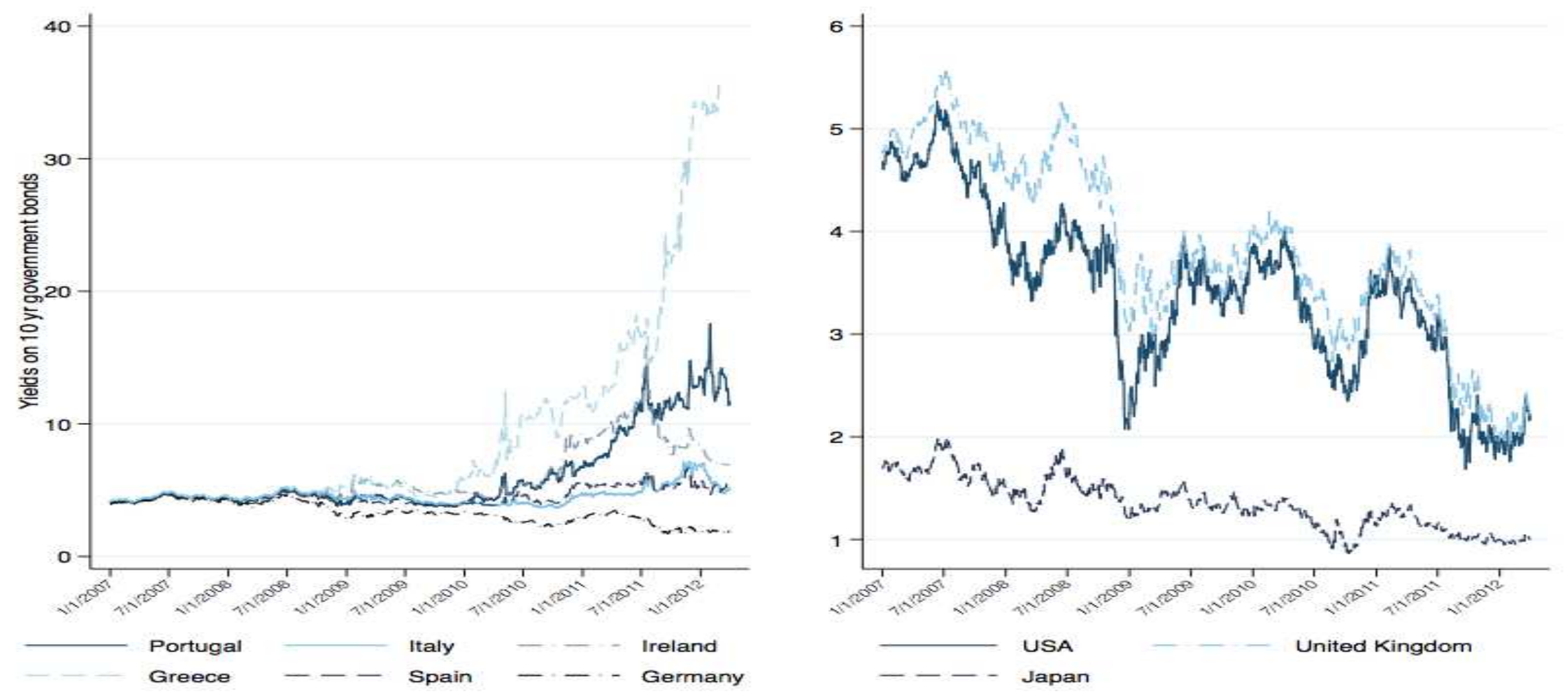

Source: Global Insight 
Figure 2: Cumulative government primary surpluses as a percent of GDP, 19992012.

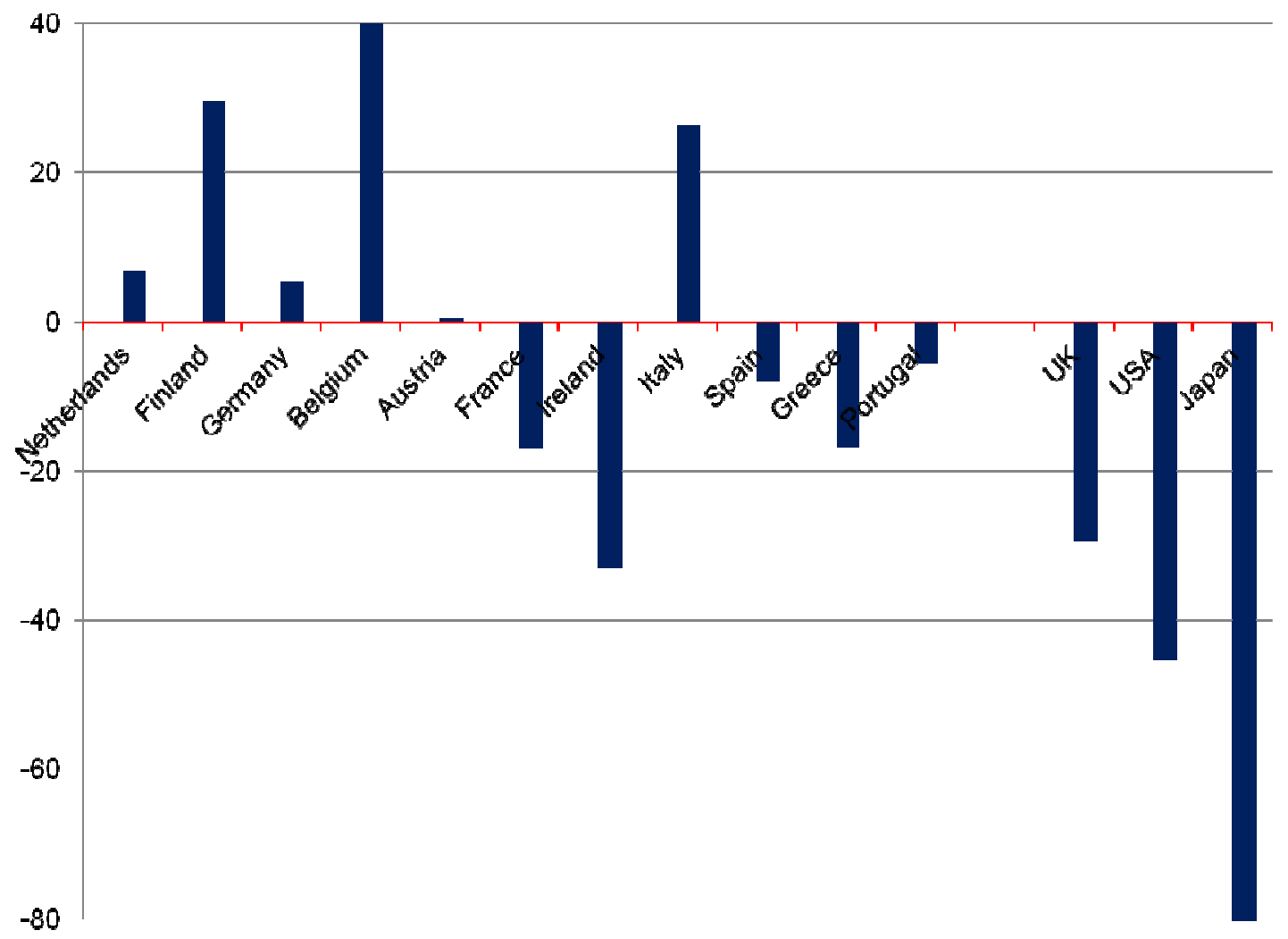

Source: International Monetary Fund, World Economic Outlook Database, September 2011. 
Figure 3: Foreign currency denominated debt and bond yields

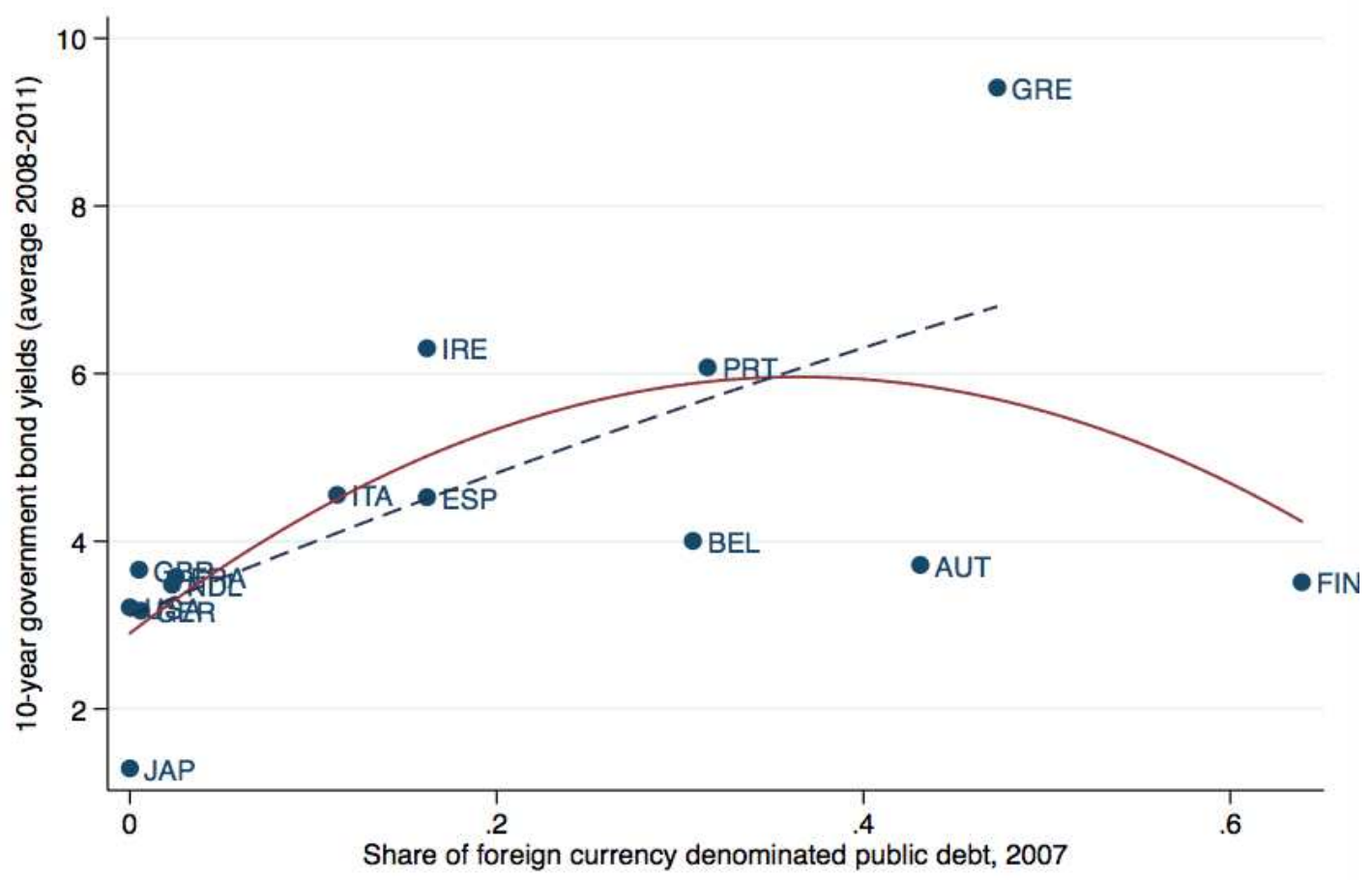

- Country Q Quadratic fit - - -- Quadratic fit, excluding Finland

Notes: Data on the share of foreign currency denominated public debt come from Panizza and Presbitero (2012), Data on 10-year yields on government bonds are from Global Insight and are averages of daily data over the period 2008-2011. 
Figure 4: A Model of Current Account and Portfolio Balances

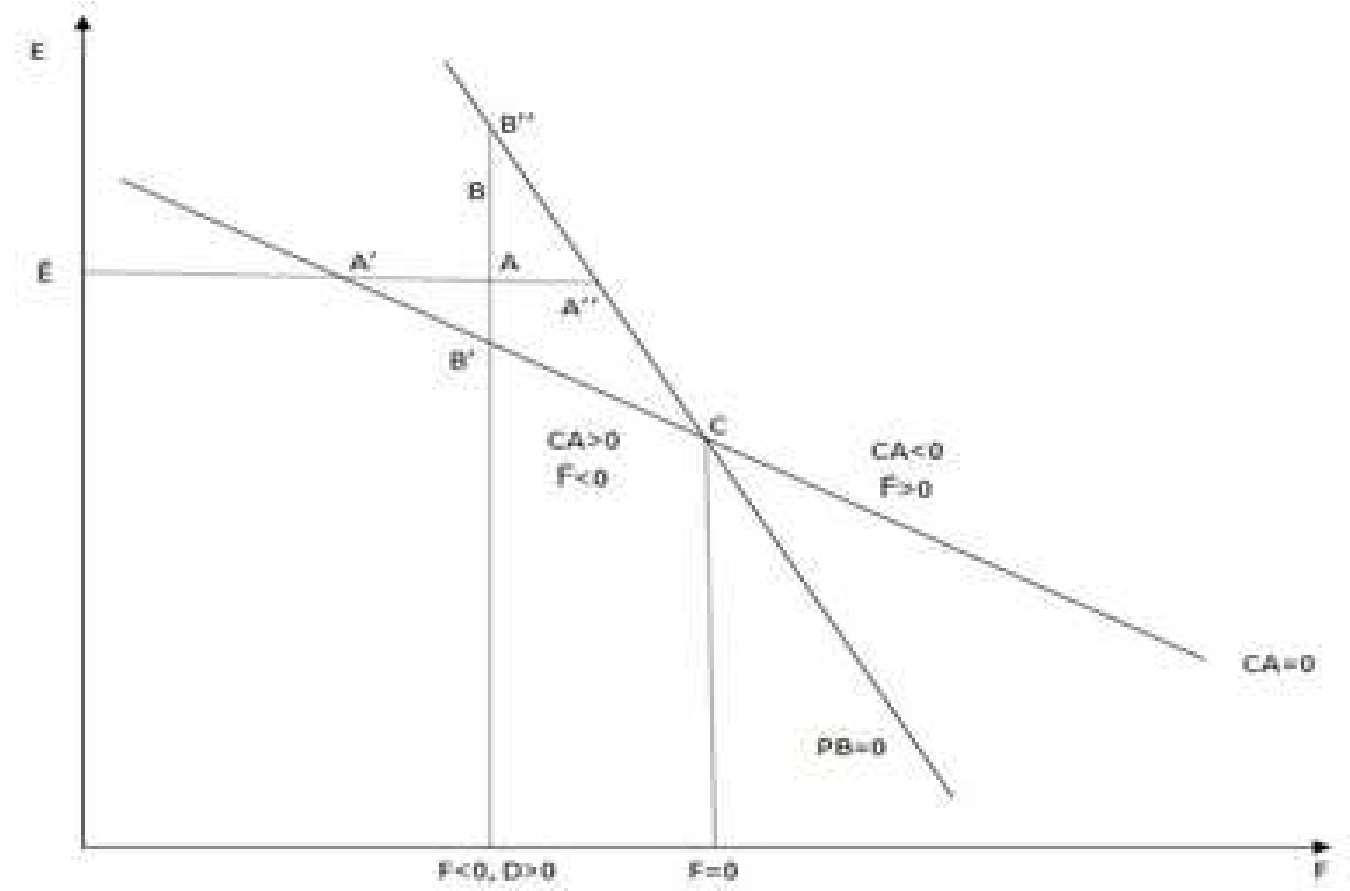


Figure 5. Global risk aversion and sovereign risk in the euro area

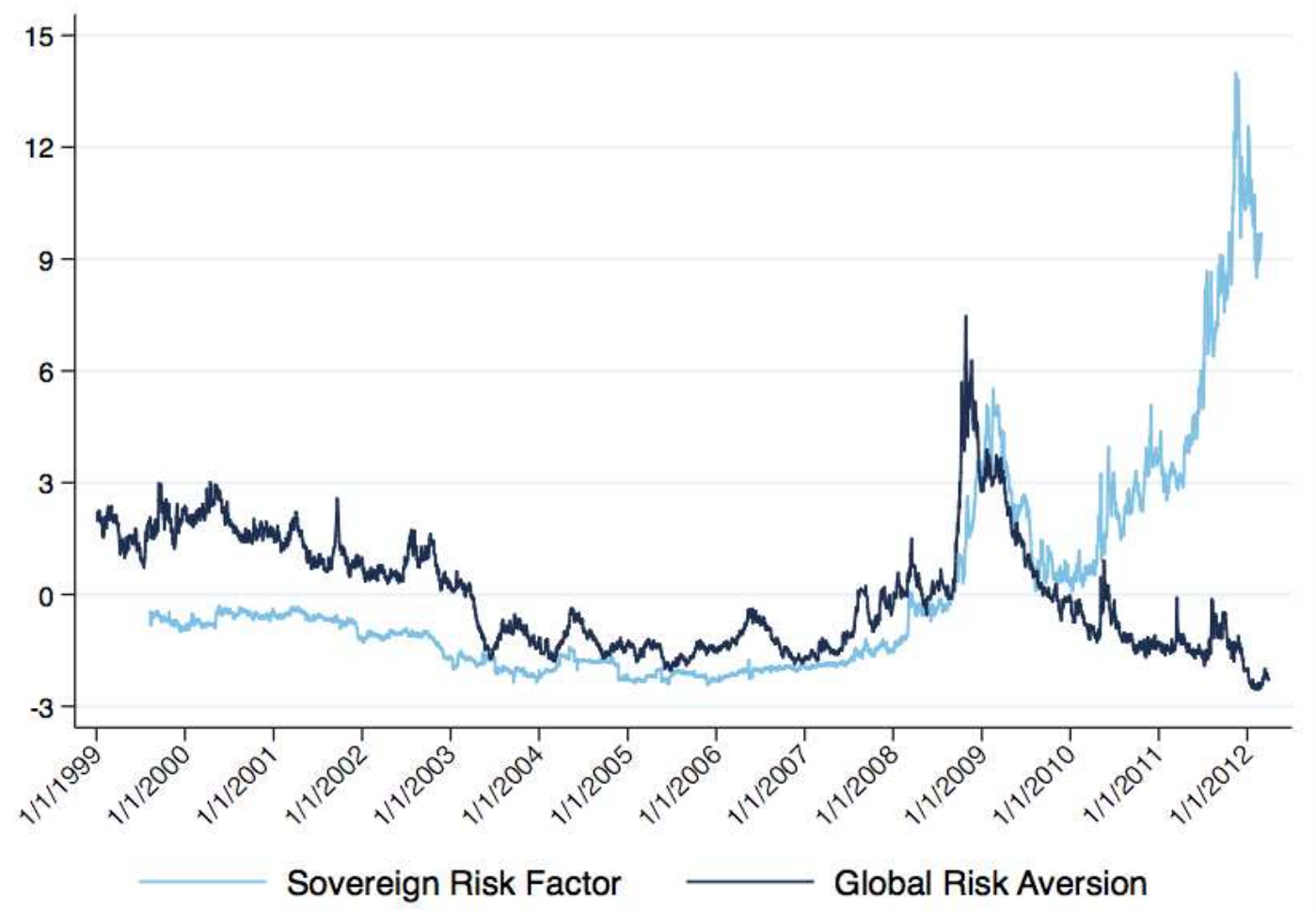

Notes: The Sovereign Risk Factor is the first principal component of the sovereign yield spreads to 10years German bunds of EMU countries. The Global Risk aversion is calculated as the first principal components of the volatility index of the OEX market, the effective long-term yields on AAA- and BBB-corporate bonds and on US, and the volatility of the euro-yen 3-months exchange rate. Daily data. See Table 4 for sources. 
Figure 6. Liquidity in the euro area sovereign 10-year bond markets

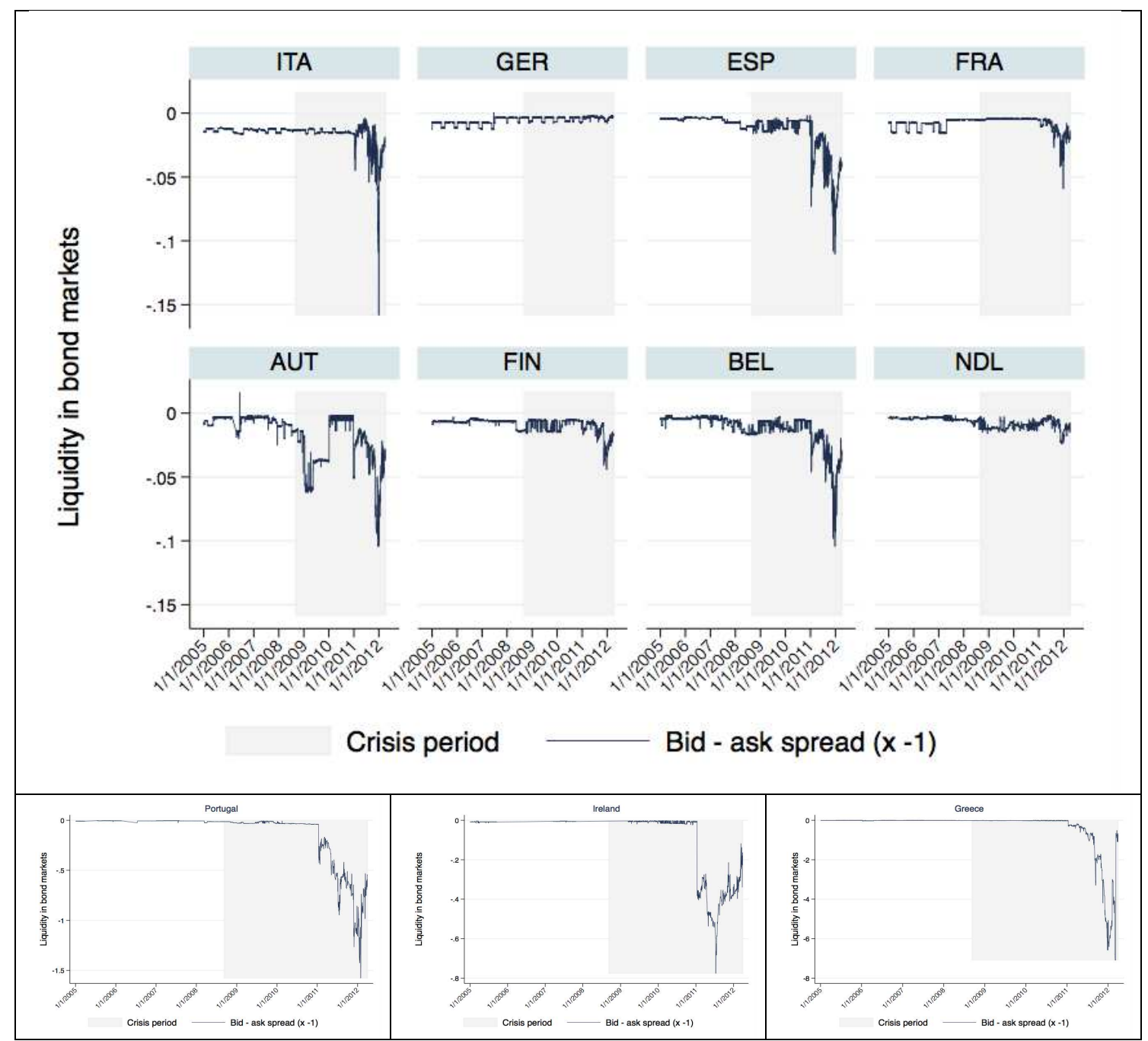

Notes: Liquidity in the secondary sovereign bond markets is measured by the opposite of the bid-ask spread. See Table 4 for details and sources. 
Figure 7. Capital reversals and sovereign spreads

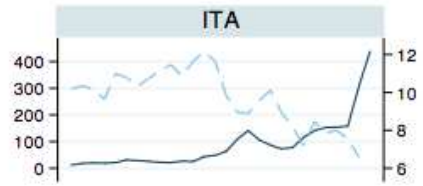

FRA

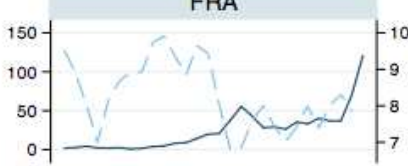

FIN

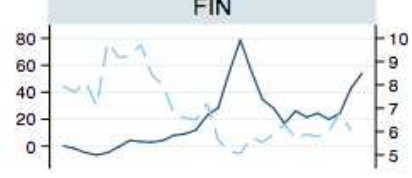

IRE

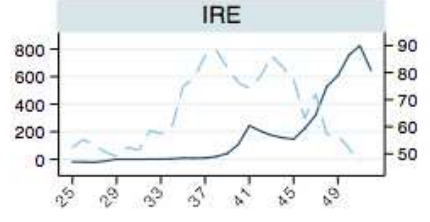

ESP

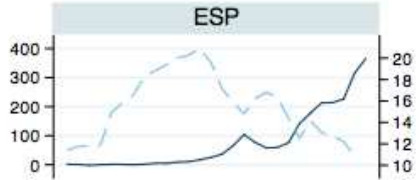

AUT

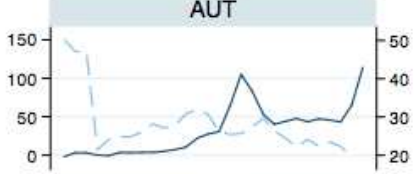

BEL

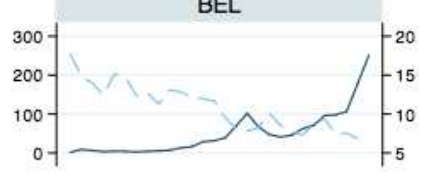

PRT

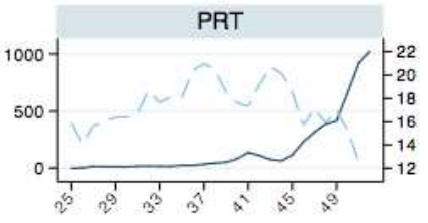

GRE

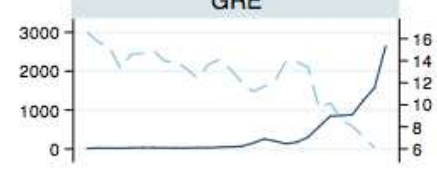

NDL

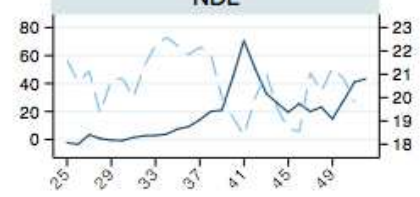

Bond spread to German 10-year bunds (left axis)

Foreign liabilities with respect to German banks over GDP (right axis) 
Table 1: Government gross debt to GDP in the euro area, UK, US, and Japan, 1999-2011

\begin{tabular}{lrrrrrrr}
\hline \multirow{2}{*}{ Country } & \multicolumn{3}{c}{ Debt to GDP } & \multicolumn{2}{c}{ Change } & \multicolumn{3}{c}{$\begin{array}{c}\text { Share of foreign } \\
\text { currency }(\%)\end{array}$} \\
\cline { 2 - 9 } & 1999 & 2007 & 2011 & $1999-2007$ & $2011-2007$ & 1999 & 2007 \\
\hline Austria & 67 & 61 & 72 & -7 & 12 & 23.7 & 43.1 \\
Belgium & 114 & 84 & 95 & -30 & 10 & 6.8 & 30.7 \\
Finland & 46 & 35 & 50 & -11 & 15 & 41.5 & 63.9 \\
France & 59 & 64 & 87 & 5 & 23 & 0.5 & 2.5 \\
Germany & 61 & 65 & 83 & 4 & 18 & 0.0 & 0.6 \\
Greece & 103 & 105 & 166 & 3 & 60 & 15.1 & 47.3 \\
Ireland & 48 & 25 & 109 & -23 & 84 & 13.8 & 16.2 \\
Italy & 114 & 104 & 121 & -10 & 17 & 0.4 & 11.3 \\
Netherlands & 61 & 45 & 66 & -16 & 20 & 0.1 & 2.3 \\
Portugal & 50 & 68 & 106 & 19 & 38 & 20.4 & 31.5 \\
Spain & 62 & 36 & 67 & -26 & 31 & 7.2 & 16.2 \\
& & & & & & & \\
United Kingdom & 44 & 44 & 81 & 0 & 37 & 1.7 & 0.5 \\
United States & 61 & 62 & 100 & 1 & 38 & 0.0 & 0.0 \\
Japan & 134 & 188 & 233 & 54 & 45 & 0.0 & 0.0 \\
\hline Source: International Monetary & Fund, World Economic & Outlook Database, September 2011, & and \\
Panizza and Presbitero (2012). & & & & & & &
\end{tabular}


Table 2. Current-account balances, unit labor costs and inflation rates, 11 euro area countries, 1999-2012

\begin{tabular}{lrrr}
\hline & \multicolumn{3}{c}{ Cumulative } \\
\cline { 2 - 4 } Country & $(\mathrm{CAB} / \mathrm{Y})^{*} 100$ & ULC \% change & CPI inflation \\
$1999-2012$ & & & $1999-2012$ \\
\hline & 79.6 & $-1999-2010$ & 30.3 \\
Netherlands & 66 & 1.4 & 26.4 \\
Finland & 52 & 8 & 21.8 \\
Germany & 32.5 & -1.5 & 29.9 \\
Belgium & 28.1 & 2.4 & 26.4 \\
Austria & -3.4 & -22.5 & 24.5 \\
France & -19.1 & 28.5 & 32.1 \\
Ireland & -24.4 & 24.8 & 30.9 \\
Italy & -75.5 & 54.9 & 38.4 \\
Spain & -123.2 & 11.1 & 43.1 \\
Greece & -132.2 & 35.1 \\
Portugal & Notes: CAB $=$ current-account balance, Y = GDP, ULC = unit labor cost, CPI = Consumer Price Index, \\
2012 values are forecast. Source: International Monetary Fund, World Economic Outlook Database, \\
September 2011 for CAB, Y and CPI inflation; OECD, Main Economic Indicators for ULC.
\end{tabular}


Table 3: Variables: description, sources and descriptive statistics

\begin{tabular}{|c|c|c|c|c|}
\hline \multirow[b]{2}{*}{ Variable } & \multirow[b]{2}{*}{ Definition } & \multirow[b]{2}{*}{ Source } & \multicolumn{2}{|c|}{ Mean } \\
\hline & & & $\begin{array}{c}2000 q 1- \\
2011 q 2 \\
(427 \text { obs.) }\end{array}$ & $\begin{array}{l}2005 q 1- \\
2011 q 2 \\
(248 \text { obs.) }\end{array}$ \\
\hline Spread & $\begin{array}{l}\text { Difference in yields to maturity of } 10 \text {-year } \\
\text { government bonds of the euro member } \\
\text { countries relative to Germany's. }\end{array}$ & $\begin{array}{l}\text { Global } \\
\text { Insight }\end{array}$ & 47.856 & 70.142 \\
\hline $\begin{array}{l}\text { Global risk } \\
\text { aversion }\end{array}$ & $\begin{array}{l}\text { General risk aversion, as the } 1 \text { st component } \\
\text { of the PCA of } 4 \text { measures of risk: OEX } \\
\text { market volatility index, US corporate AAA } \\
\text { and BBB yields and Euro-Yen } 3 \text {-months } \\
\text { exchange rate volatility. Quarterly averages } \\
\text { from daily data. }\end{array}$ & $\begin{array}{l}\text { Global } \\
\text { Insight and } \\
\text { FRED }\end{array}$ & -0.099 & -0.391 \\
\hline Bid-Ask & $\begin{array}{l}\text { Bid-ask spread in 10-year government } \\
\text { bond market relative to German values, per } \\
\text { cent. Quarterly averages from daily data. }\end{array}$ & Bloomberg & 0.621 & 1.045 \\
\hline $\begin{array}{l}\text { Primary } \\
\text { balance }\end{array}$ & $\begin{array}{l}\text { Primary balance over GDP relative to } \\
\text { German values, per cent. Quarterly data. } \\
\text { Since data are not seasonally adjusted, the } \\
\text { variable is a }\left(\begin{array}{lll}2 & 1 & 2\end{array}\right) \text { moving average. . }\end{array}$ & Eurostat & -0.326 & -1.934 \\
\hline Public debt & $\begin{array}{l}\text { Gross government debt over GDP relative } \\
\text { to German values, per cent.Quarterly. }\end{array}$ & Eurostat & 5.029 & 2.806 \\
\hline Growth & $\begin{array}{l}\text { Quarterly GDP growth relative to German } \\
\text { values, percentage change with respect to } \\
\text { corresponding quarter of previous year. }\end{array}$ & Eurostat & 0.411 & -0.319 \\
\hline Inflation & $\begin{array}{l}\text { Quarterly inflation relative to German } \\
\text { values of the monthly HICP index number } \\
(2005=100)\end{array}$ & Eurostat & -0.604 & 0.733 \\
\hline $\begin{array}{l}\text { Labor } \\
\text { productivity }\end{array}$ & $\begin{array}{l}\text { Quarterly real labor productivity per } \\
\text { employee relative to German values, } \\
\text { percentage change on previous period } \\
\text { (seasonally adjusted and adjusted by } \\
\text { working days). }\end{array}$ & Eurostat & 0.029 & 0.052 \\
\hline Trade balance & $\begin{array}{l}\text { Trade balance over GDP relative to } \\
\text { German values, per cent. Quarterly. }\end{array}$ & Eurostat & 0.451 & 0.277 \\
\hline $\begin{array}{l}\text { Liabilities to } \\
\text { German } \\
\text { banks }\end{array}$ & $\begin{array}{l}\text { Financial liabilities vis-a-vis German banks } \\
\text { over GDP, per cent. }\end{array}$ & $\begin{array}{l}\text { BIS and } \\
\text { Eurostat }\end{array}$ & - & 18.188 \\
\hline PRR & $\begin{array}{l}\text { Political Risk Rating (0-100): one of the } \\
\text { ICRG indexes, based on several political } \\
\text { risk components. Data are taken as a } \\
\text { difference form German values. }\end{array}$ & $\begin{array}{l}\text { The PRS } \\
\text { Group }\end{array}$ & -1.649 & -2.640 \\
\hline $\begin{array}{l}\text { Post } 2010 \\
(0,1)\end{array}$ & $\begin{array}{l}\text { Dummy equal to one since } 2010 q 1 \text {, } \\
\text { included, and zero otherwise. }\end{array}$ & - & 0.138 & 0.238 \\
\hline Greece $(0,1)$ & Dummy for Greece. & - & 0.012 & 0.020 \\
\hline PIIS $(0,1)$ & $\begin{array}{l}\text { Dummy for Portugal, Ireland, Italy and } \\
\text { Spain. }\end{array}$ & - & 0.056 & 0.097 \\
\hline
\end{tabular}


Table 4: Determinants of 10-year government bond spreads relative to German Bunds, Euro Area; quarterly data from 2000q1 to $2011 q 2$.

\begin{tabular}{|c|c|c|c|c|c|}
\hline Dep. Var.: Spread & (1) & (2) & (3) & $(4)$ & (5) \\
\hline Global risk aversion & $\begin{array}{c}2.291 \\
\end{array}$ & $\begin{array}{c}2.426 \\
\end{array}$ & $\begin{array}{c}2.027 \\
\end{array}$ & $\begin{array}{l}6.623 * * \\
{[2.836]}\end{array}$ & $\begin{array}{l}6.352 * * \\
{[2.843]}\end{array}$ \\
\hline Bid-Ask & $\begin{array}{c}7.982 * * * \\
{[1.214]}\end{array}$ & $\begin{array}{c}8.164 * * * \\
{[1.200]}\end{array}$ & $\begin{array}{c}8.053 * * * \\
{[1.210]}\end{array}$ & $\begin{array}{c}8.360 * * * \\
{[1.354]}\end{array}$ & $\begin{array}{c}8.477 * * * \\
{[1.341]}\end{array}$ \\
\hline Primary balance & $\begin{array}{c}-3.683 * * * \\
{[1.169]}\end{array}$ & $\begin{array}{c}-3.690 * * * \\
{[1.171]}\end{array}$ & $\begin{array}{c}-3.546 * * * \\
{[1.206]}\end{array}$ & $\begin{array}{c}-3.396 * * * \\
{[0.880]}\end{array}$ & $\begin{array}{c}-3.224 * * * \\
{[0.869]}\end{array}$ \\
\hline Public debt & $\begin{array}{c}3.320 * * * \\
{[0.541]}\end{array}$ & $\begin{array}{c}3.156 * * * \\
{[0.554]}\end{array}$ & $\begin{array}{c}3.258 * * * \\
{[0.534]}\end{array}$ & $\begin{array}{c}2.111 * * * \\
{[0.423]}\end{array}$ & $\begin{array}{c}1.924 * * * \\
{[0.415]}\end{array}$ \\
\hline Growth & $\begin{array}{c}-9.327 * * * \\
{[2.380]}\end{array}$ & $\begin{array}{c}-9.555 * * * \\
{[2.387]}\end{array}$ & $\begin{array}{c}-9.169 * * * \\
{[2.368]}\end{array}$ & $\begin{array}{c}-4.960 * * \\
{[2.212]}\end{array}$ & $\begin{array}{c}-4.825^{* *} \\
{[2.145]}\end{array}$ \\
\hline Inflation & $\begin{array}{l}4.195^{*} \\
{[2.410]}\end{array}$ & $\begin{array}{l}4.467 * \\
{[2.376]}\end{array}$ & $\begin{array}{l}4.114 * \\
{[2.394]}\end{array}$ & $\begin{array}{c}3.216 \\
{[1.975]}\end{array}$ & $\begin{array}{l}3.352 * \\
{[2.008]}\end{array}$ \\
\hline Labor productivity & $\begin{array}{c}-8.080 * * * \\
{[2.418]}\end{array}$ & $\begin{array}{c}-8.107 * * * * \\
{[2.429]}\end{array}$ & $\begin{array}{c}-8.012 * * * \\
{[2.435]}\end{array}$ & $\begin{array}{c}-9.425 * * * \\
{[2.584]}\end{array}$ & $\begin{array}{c}-9.299 * * * \\
{[2.585]}\end{array}$ \\
\hline Trade balance & & $\begin{array}{c}0.844 \\
{[1.126]}\end{array}$ & & & $\begin{array}{c}0.978 \\
{[1.203]}\end{array}$ \\
\hline Political risk & & & $\begin{array}{c}-0.756 \\
{[1.296]}\end{array}$ & & $\begin{array}{c}-0.793 \\
{[1.044]}\end{array}$ \\
\hline Post $2010(0,1)$ & & & & $\begin{array}{c}17.770^{* *} \\
{[8.633]}\end{array}$ & $\begin{array}{c}21.172 * * \\
{[8.750]}\end{array}$ \\
\hline Greece x Post 2010 & & & & $\begin{array}{c}427.976 * * * \\
{[46.925]}\end{array}$ & $\begin{array}{c}423.256 * * * \\
{[46.438]}\end{array}$ \\
\hline PIIS x Post 2010 & & & & $\begin{array}{c}78.485^{* * * *} \\
{[17.293]}\end{array}$ & $\begin{array}{c}74.235^{* * *} * \\
{[17.945]}\end{array}$ \\
\hline Observations & 427 & 427 & 427 & 427 & 427 \\
\hline R-squared & 0.771 & 0.782 & 0.774 & 0.878 & 0.881 \\
\hline Number of Countries & 10 & 10 & 10 & 10 & 10 \\
\hline \multicolumn{6}{|c|}{$\begin{array}{l}\text { Notes: The table reports the regression coefficients of Panel-Corrected Standard Error (PCSE) } \\
\text { estimates for linear cross-sectional time-series models. The disturbances are assumed heteroskedastic } \\
\text { and contemporaneously correlated across panels. Within panels, there is first-order autocorrelation and } \\
\text { the coefficient of the AR(1) process is specific to each panel. The associated robust standard errors are } \\
\text { reported in brackets. * significant at } 10 \% \text {; ** significant at 5\%; *** significant at } 1 \% \text {. A constant and } \\
\text { nine country dummies are included but not showed. }\end{array}$} \\
\hline
\end{tabular}


Table 5: Determinants of 10-year government yield spreads relative to German Bunds, Euro Area; quarterly data from $2005 q 1$ to $2011 q 2$.

\begin{tabular}{|c|c|c|c|c|}
\hline Dep. Var.: Spread & $(1)$ & $(2)$ & (3) & $(4)$ \\
\hline \multirow[t]{2}{*}{ Global risk aversion } & 6.300 & $6.828^{*}$ & 5.707 & $7.405 * *$ \\
\hline & [3.933] & [3.904] & {$[3.818]$} & {$[3.375]$} \\
\hline \multirow[t]{2}{*}{ Bid-Ask } & $7.859 * * *$ & $7.997 * * *$ & $6.830 * * *$ & $6.867 * * *$ \\
\hline & [1.523] & [1.533] & [1.344] & [1.391] \\
\hline \multirow[t]{2}{*}{ Primary balance } & 0.928 & 1.372 & 0.305 & -1.939 \\
\hline & [1.926] & {$[1.920]$} & [1.847] & {$[1.344]$} \\
\hline \multirow[t]{2}{*}{ Public debt } & $6.100 * * *$ & $6.058 * * *$ & $6.438 * * *$ & $4.503 * * *$ \\
\hline & [0.968] & [0.965] & [0.913] & {$[0.854]$} \\
\hline \multirow[t]{2}{*}{ Growth } & $-13.674 * * *$ & $-13.871 * * *$ & $-12.949 * * *$ & $-5.555^{*}$ \\
\hline & [3.336] & [3.318] & [3.079] & [2.930] \\
\hline \multirow[t]{2}{*}{ Inflation } & $10.085^{* *}$ & $10.488 * *$ & $12.425^{* * *}$ & 5.601 \\
\hline & [4.693] & [4.593] & [4.122] & {$[3.795]$} \\
\hline \multirow[t]{2}{*}{ Labor productivity } & $-14.756 * * *$ & $-15.011 * * *$ & $-13.302 * * *$ & $-14.764 * * *$ \\
\hline & [4.308] & [4.359] & [3.914] & [3.676] \\
\hline \multirow[t]{2}{*}{ Trade balance } & & 1.647 & & \\
\hline & & {$[2.030]$} & & \\
\hline \multirow[t]{2}{*}{ Liabilities to German banks } & & & $-3.770 * * *$ & $-2.057 * * *$ \\
\hline & & & {$[0.903]$} & {$[0.770]$} \\
\hline \multirow[t]{2}{*}{ Post $2010(0,1)$} & & & & 7.817 \\
\hline & & & & [11.222] \\
\hline \multirow[t]{2}{*}{ Greece x Post 2010} & & & & $385.388 * * *$ \\
\hline & & & & [59.188] \\
\hline \multirow[t]{2}{*}{ PIIS x Post 2010} & & & & $61.453^{* * *}$ \\
\hline & & & & {$[15.885]$} \\
\hline Observations & 248 & 248 & 248 & 248 \\
\hline R-squared & 0.777 & 0.786 & 0.821 & 0.896 \\
\hline Number of Countries & 10 & 10 & 10 & 10 \\
\hline \multicolumn{5}{|c|}{$\begin{array}{l}\text { Notes: The table reports the regression coefficients of Panel-Corrected Standard Error (PCSE) } \\
\text { estimates for linear cross-sectional time-series models. The disturbances are assumed heteroskedastic } \\
\text { and contemporaneously correlated across panels. Within panels, there is first-order autocorrelation and } \\
\text { the coefficient of the AR(1) process is specific to each panel. The associated robust standard errors are } \\
\text { reported in brackets. * significant at } 10 \% \text {; ** significant at 5\%; *** significant at } 1 \% \text {. A constant and } \\
\text { nine country dummies are included but not showed. }\end{array}$} \\
\hline
\end{tabular}


Table 6: Contributions of explanatory variables to Eurozone sovereign yield spreads

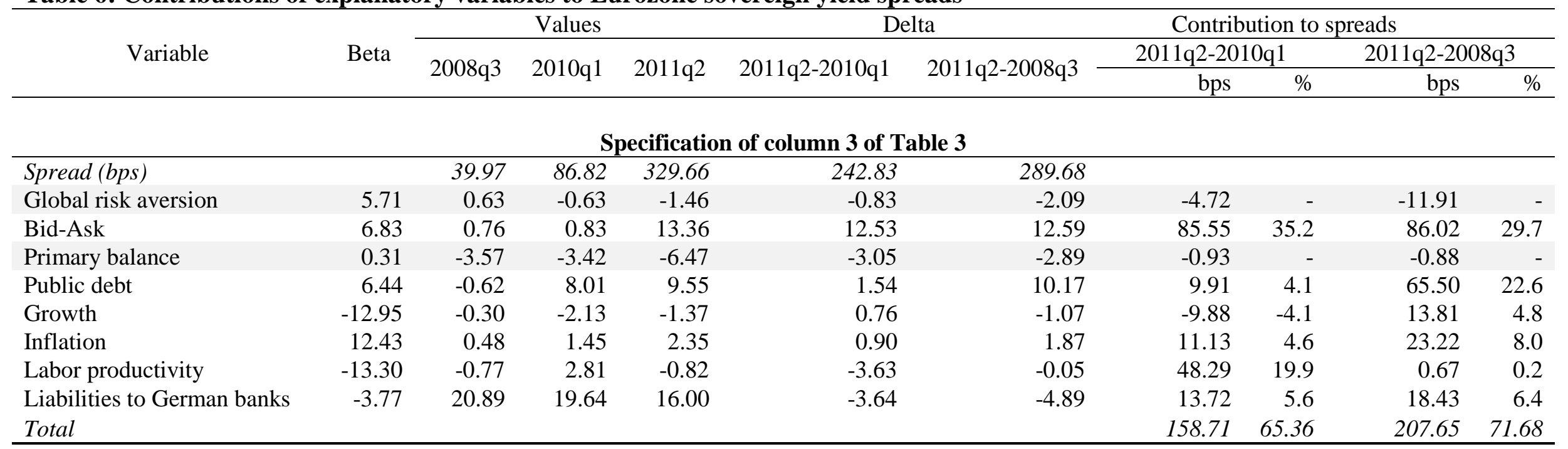

Total

Specification of column 4 of Table 3

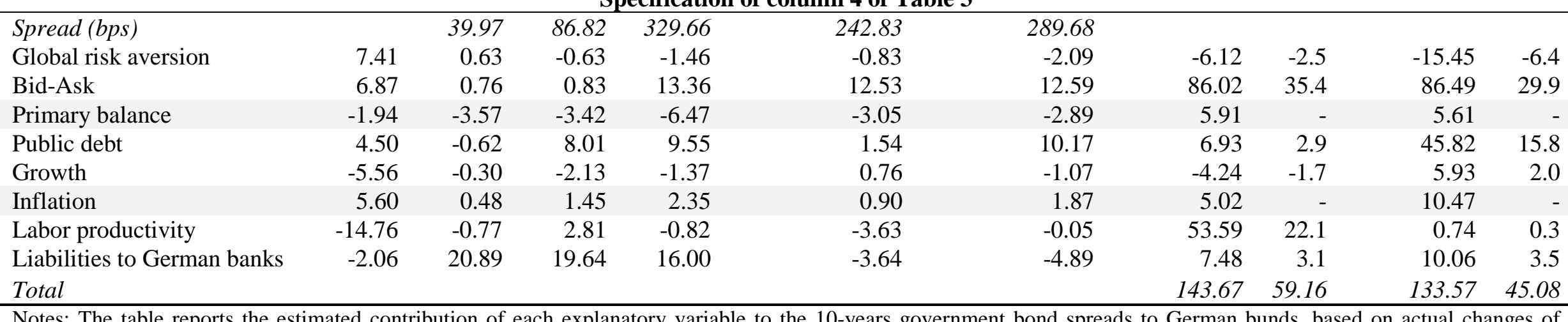

Notes: The table reports the estimated contribution of each explanatory variable to the 10-years government bond spreads to German bunds, based on actual changes of explanatory variables over different sample periods. Calculations are based on the coefficients reported in Table 5 (columns 3 and 4 ). The grey line indicates variables whose coefficients are not statistically significant in the regression. 
Table 7: Testing for structural breaks

\begin{tabular}{|c|c|c|c|c|c|c|}
\hline & \multicolumn{3}{|c|}{ Base model } & \multicolumn{3}{|c|}{ Model including bank loans } \\
\hline & $\begin{array}{c}\text { pre-2010 } \\
\text { (1) }\end{array}$ & $\begin{array}{c}\text { post-2010 } \\
(2)\end{array}$ & $\begin{array}{c}\text { t-test } \\
(3)\end{array}$ & $\begin{array}{c}\text { pre-2010 } \\
\text { (4) }\end{array}$ & $\begin{array}{c}\text { post- } 2010 \\
(5)\end{array}$ & $\begin{array}{c}\text { t-test } \\
(6)\end{array}$ \\
\hline $\begin{array}{l}\text { Global risk } \\
\text { aversion }\end{array}$ & $\begin{array}{c}8.721 * * * \\
(1.427)\end{array}$ & $\begin{array}{c}-119.058 * * * \\
(19.955)\end{array}$ & $\begin{array}{c}40.62 \\
0.00\end{array}$ & $\begin{array}{c}10.753 * * * \\
(1.485)\end{array}$ & $\begin{array}{c}-133.367 * * * \\
(16.479)\end{array}$ & $\begin{array}{c}75.70 \\
0.00\end{array}$ \\
\hline Primary balance & $\begin{array}{c}-2.844 * * * \\
(0.768)\end{array}$ & $\begin{array}{l}-2.203 \\
(1.901)\end{array}$ & $\begin{array}{l}0.10 \\
0.76\end{array}$ & $\begin{array}{c}0.365 \\
(1.025)\end{array}$ & $\begin{array}{l}-2.491 \\
(2.103)\end{array}$ & $\begin{array}{l}1.49 \\
0.22\end{array}$ \\
\hline Public debt & $\begin{array}{c}1.541 * * * \\
(0.275)\end{array}$ & $\begin{array}{c}7.012 * * * \\
(1.590)\end{array}$ & $\begin{array}{c}11.36 \\
0.00\end{array}$ & $\begin{array}{c}3.800 * * * \\
(0.532)\end{array}$ & $\begin{array}{c}8.623 * * * \\
(1.451)\end{array}$ & $\begin{array}{l}9.50 \\
0.00\end{array}$ \\
\hline Growth & $\begin{array}{l}-1.686 \\
(1.209)\end{array}$ & $\begin{array}{c}-24.736 * * * \\
(5.616)\end{array}$ & $\begin{array}{c}16.10 \\
0.00\end{array}$ & $\begin{array}{c}-3.019 * * \\
(1.292)\end{array}$ & $\begin{array}{c}-27.437 * * * \\
(5.611)\end{array}$ & $\begin{array}{c}17.91 \\
0.00\end{array}$ \\
\hline Bid-Ask & $\begin{array}{c}10.999 * * * \\
(2.311)\end{array}$ & $\begin{array}{c}3.869 * * * \\
(1.056)\end{array}$ & $\begin{array}{l}7.85 \\
0.01\end{array}$ & $\begin{array}{c}11.416 * * * \\
(2.207)\end{array}$ & $\begin{array}{l}1.660^{*} \\
(0.888)\end{array}$ & $\begin{array}{c}16.66 \\
0.00\end{array}$ \\
\hline Inflation & $\begin{array}{c}4.567 * * * \\
(1.023)\end{array}$ & $\begin{array}{c}-25.786 * * * \\
(5.476)\end{array}$ & $\begin{array}{c}29.82 \\
0.00\end{array}$ & $\begin{array}{c}8.376 * * * \\
(2.205)\end{array}$ & $\begin{array}{c}-15.521 * * * \\
(5.340)\end{array}$ & $\begin{array}{c}17.43 \\
0.00\end{array}$ \\
\hline $\begin{array}{l}\text { Labor } \\
\text { productivity }\end{array}$ & $\begin{array}{c}1.004 \\
(1.589)\end{array}$ & $\begin{array}{c}-34.917 * * * \\
(6.481)\end{array}$ & $\begin{array}{c}29.05 \\
0.00\end{array}$ & $\begin{array}{l}-0.528 \\
(1.835)\end{array}$ & $\begin{array}{c}-30.849 * * * \\
(5.372)\end{array}$ & $\begin{array}{c}29.11 \\
0.00\end{array}$ \\
\hline $\begin{array}{l}\text { Liabilities to } \\
\text { German banks }\end{array}$ & & & & $\begin{array}{l}-0.580 \\
(0.407)\end{array}$ & $\begin{array}{c}-11.538 * * * \\
(2.035)\end{array}$ & $\begin{array}{c}27.90 \\
0.00\end{array}$ \\
\hline $\begin{array}{l}\text { Chow test } \\
\text { (p-value) } \\
\text { Observations } \\
\text { R-squared } \\
\text { N. of Countries }\end{array}$ & & $\begin{array}{c}63.04 \\
0.00 \\
427 \\
0.949 \\
10\end{array}$ & & & $\begin{array}{c}122.52 \\
0.00 \\
248 \\
0.969 \\
10\end{array}$ & \\
\hline
\end{tabular}

Notes: The table reports the regression coefficients of Panel-Corrected Standard Error (PCSE) estimates for linear cross-sectional time-series models. The disturbances are assumed heteroskedastic and contemporaneously correlated across panels. Within panels, there is first-order autocorrelation and the coefficient of the $\mathrm{AR}(1)$ process is specific to each panel. The associated robust standard errors are reported in brackets. * significant at $10 \%$; * significant at $5 \%$; *** significant at $1 \%$. The base model refers to the specification reported in column 1 of Table 2, while the model including bank loans refers to the specification reported in column 3 of Table 3. Each explanatory variable is interacted with the Post 2010 dummy in order to have separate coefficients for the pre- and the post-2010 periods, reported in columns (1)-(4) and (2)-(5), respectively. The t-tests and the associated p-values for equality of coefficients across the two sub-periods are reported in columns (3) and (6). The Chow tests for the presence of a structural break between pre- and post-2010 are reported at the bottom of the Table. A constant, the Post 2010 dummy, and nine country dummies (each one interacted with the Post 2010 dummy) are included in both specifications but not showed. 